\title{
Effect of methylene blue on the genomic response to reperfusion injury induced by cardiac arrest and cardiopulmonary resuscitation in porcine brain
}

\author{
Cécile Martijn* and Lars Wiklund
}

\begin{abstract}
Background: Cerebral ischemia/reperfusion injury is a common secondary effect of cardiac arrest which is largely responsible for postresuscitative mortality. Therefore development of therapies which restore and protect the brain function after cardiac arrest is essential. Methylene blue (MB) has been experimentally proven neuroprotective in a porcine model of global ischemia-reperfusion in experimental cardiac arrest. However, no comprehensive analyses have been conducted at gene expression level.
\end{abstract}

Methods: Pigs underwent either untreated cardiac arrest (CA) or CA with subsequent cardiopulmonary resuscitation (CPR) accompanied with an infusion of saline or an infusion of saline with MB. Genome-wide transcriptional profiling using the Affymetrix porcine microarray was performed to 1) gain understanding of delayed neuronal death initiation in porcine brain during ischemia and after 30,60 and 180 min following reperfusion, and 2) identify the mechanisms behind the neuroprotective effect of MB after ischemic injury (at 30,60 and $180 \mathrm{~min}$ ).

Results: Our results show that restoration of spontaneous circulation (ROSC) induces major transcriptional changes related to stress response, inflammation, apoptosis and even cytoprotection. In contrast, the untreated ischemic and anoxic insult affected only few genes mainly involved in intra-/extracellular ionic balance. Furthermore, our data show that the neuroprotective role of $\mathrm{MB}$ is diverse and fulfilled by regulation of the expression of soluble guanylate cyclase and biological processes accountable for inhibition of apoptosis, modulation of stress response, neurogenesis and neuroprotection.

Conclusions: Our results support that MB could be a valuable intervention and should be investigated as a therapeutic agent against neural damage associated with I/R injury induced by cardiac arrest.

\section{Background}

Despite recent advances in out-of-hospital cardiac arrest (CA) resuscitation, hypoxic-ischemic brain damage still causes considerable mortality and morbidity. Of the patients who survive to discharge, only $20 \%$ or fewer will have good neurologic function at the end of 1 year [1] After successful CPR and restoration of spontaneous circulation (ROSC) neuronal death initiated by ischemia during $C A$ is increased also during reperfusion leading to secondary postischemic-anoxic encephalopathy [2], part of the so-called postresuscitation syndrome $[3,4]$. Cerebral recovery is dependent on duration of arrest and car-

* Correspondence: cecile.martijn@surgsci.uu.se

1 Department of Surgical Sciences/Anaesthesiology and Intensive Care Medicine, Uppsala University Hospital, SE-751 85 Uppsala, Sweden Full list of author information is available at the end of the article diopulmonary resuscitation (CPR), and numerous factors related to basic, advanced, and prolonged life support $[5,6]$. Except for the use of mild hypothermia after ventricular fibrillation cardiac arrest, currently recommended therapy in the 2005 guidelines of the European Resuscitation Council [7], clinical neuroprotection practice rests solely on extrapolation from animal experimental work or weak clinical studies[8]. In recent years, especially in critical care research, swine have increasingly been employed because they share similar cardiovascular and physiologic properties with humans $[9,10]$. Furthermore, porcine brains, like human, are gyrencephalic which make them closely related to the human brain in structure and function. Accordingly, the response of pigs to disease and treatment are often comparable to 
that of human [11] and data concerning pig brain anatomy and neurochemistry have increased considerably in recent years $[12,13]$.

Safety/FDA approved methylene Blue (MB), a cationic thiazine dye with a low toxicity profile at low doses, is efficiently trapped in the brain and its concentration is over 10 times higher in the brain than in the circulation one hour after systemic administration [14], indicating a rapid and extensive accumulation in the nervous system. MB has been used as a neuroprotective agent in druginduced encephalopathy, dementia and manic-depressive psychosis [15-17]. Furthermore, MB exhibits promising cardio- and neuroprotective properties in experimental cardiac arrest $[18,19]$ and is effective in both attenuating ischemia-reperfusion (I/R) syndrome [20] and increasing short-term survival after resuscitation from cardiac arrest [21].

In order to gain further understanding of the mechanisms behind the neuroprotective effects of $\mathrm{MB}$, we conducted a microarray analysis of the changes in gene expression in the ischemic brain in our pig model of experimental cardiac arrest and subsequent ischemiareperfusion injury.

\section{Methods}

Animal treatment and experimental procedures were approved by the Uppsala Institutional Review Board for Animal Experimentation. The piglets were handled according to the guidelines of the Swedish National Board for Laboratory Animals and the European Convention of Animal Care. Anaesthesia was used in all surgical interventions.

\section{Animals}

Experiments were performed on 30 piglets of Swedish triple breed of both sexes aged 12-14 weeks and with a mean weight of $25.8 \mathrm{~kg} \pm 1.3 \mathrm{~kg}$.

\section{Cardiac arrest model}

Previous use of the same model of extended cardiac arrest (12 min of untreated cardiac arrest (CA) and $8 \mathrm{~min}$ of cardiopulmonary resuscitation (CPR) has already been described [19]. Here we used the same anaesthesia, fluid administration surgical preparation and experimental protocol to induce CA. Return of spontaneous circulation and post-resuscitative treatments either with normal saline or with $\mathrm{MB}$ were administered following the protocol previously described by our group [18]. After completion of study, all animals received an injection of $10 \mathrm{~mL}$ potassium chloride $20 \mathrm{mmol} / \mathrm{mL}$ and were sacrificed. In all the animals the skull was opened in prone position immediately before death and the brain was taken out and frozen in liquid nitrogen within $1 \mathrm{~min}$ after death. Thirty pigs were divided into three groups. The first group $(\mathrm{CA}, \mathrm{n}=12)$ underwent untreated CA. The brain of the animals was removed either immediately after $\mathrm{CA}$ $(\mathrm{Ca} 0 \mathrm{n}=3)$, or after $5 \mathrm{~min}(\mathrm{Ca} 5 \mathrm{n}=3), 20 \min (\mathrm{Ca} 20 \mathrm{n}=$ 3 ) and $30 \min (\mathrm{Ca} 30 \mathrm{n}=3)$ respectively (Figure $1 \mathrm{~A})$. The other two groups underwent CA followed by CPR and received either an infusion saline (ROSC $n=9$ ) or an infusion of $\mathrm{MB}(10 \mathrm{mg} / \mathrm{mL}$ Metyltioninklorid, Apoteket, Umeå, Sweden) with saline (MB $n=9)$ as described in Figure 1B. Brain samples from resuscitated animals were collected at $30 \mathrm{~min}$ (Rosc30 and MB30 groups), $60 \mathrm{~min}$ (Rosc60 and MB60 groups) or $180 \mathrm{~min}$ (Rosc180 and MB180 groups) after ROSC.

\section{RNA extraction}

Total RNA was extracted using RNeasy Lipid Tissue kit (Qiagen)according to the manufacturer's instructions. Contaminating genomic DNA was removed during RNA purification by addition of an on-column DNase digestion step with RNase-Free Dnase I (Qiagen). RNA quality was verified on an Agilent 2100 Bioanalyzer (Agilent).

\section{Affymetrix gene profiling and microarray analysis}

Total RNA $(10 \mu \mathrm{g})$ was first converted to double-stranded cDNA (One-cycle cDNA synthesis kit, Affymetrix UK Ltd) and then to biotinylated cRNA (IVT labelling kit, Affymetrix UK Ltd) as described in the One-cycle Target Labelling protocol (Affymetrix UK Ltd). After fragmentation and quality confirmation (Agilent 2100 Bioanalyzer), $10 \mu \mathrm{g}$ of the biotinylated cRNA were hybridized for 16 hours to an Affymetrix GeneChip Porcine Genome Array. The array was then washed and stained with streptavidin-phycoerythrin solution using the Fluidics Station 450 (Affymetrix UK Ltd.) before it was scanned using the Affymetrix GeneChip Scanner 3000. Data were normalized and comparative analysis results were obtained from Affymetrix GeneChip Operating Software (GCOS v1.4; Affymetrix UK Ltd). The results were deposited to GEO database under accession number GSE22165. Statistical analysis was performed using the Significance Analysis of Microarrays (SAM) statistics program to determine genes that were significantly regulated at each time point [22]. SAM uses a permutation method to determine the significance of changes in expression by assimilating a set of gene-specific $\mathrm{t}$-tests and hence reports a false-discovery rate (FDR) rather than a probability. Data query, mining, filtering and sorting as well as hierarchical cluster analysis and principle component analysis (PCA) were performed using Spotfire DecisionSite for Functional Genomics software (Tibco-Spotfire Inc., Cambridge, MA, USA).

\section{Gene filtering and selection}

In a first step, after normalization, results from the GeneChip Operating Software (GCOS) were considered. 

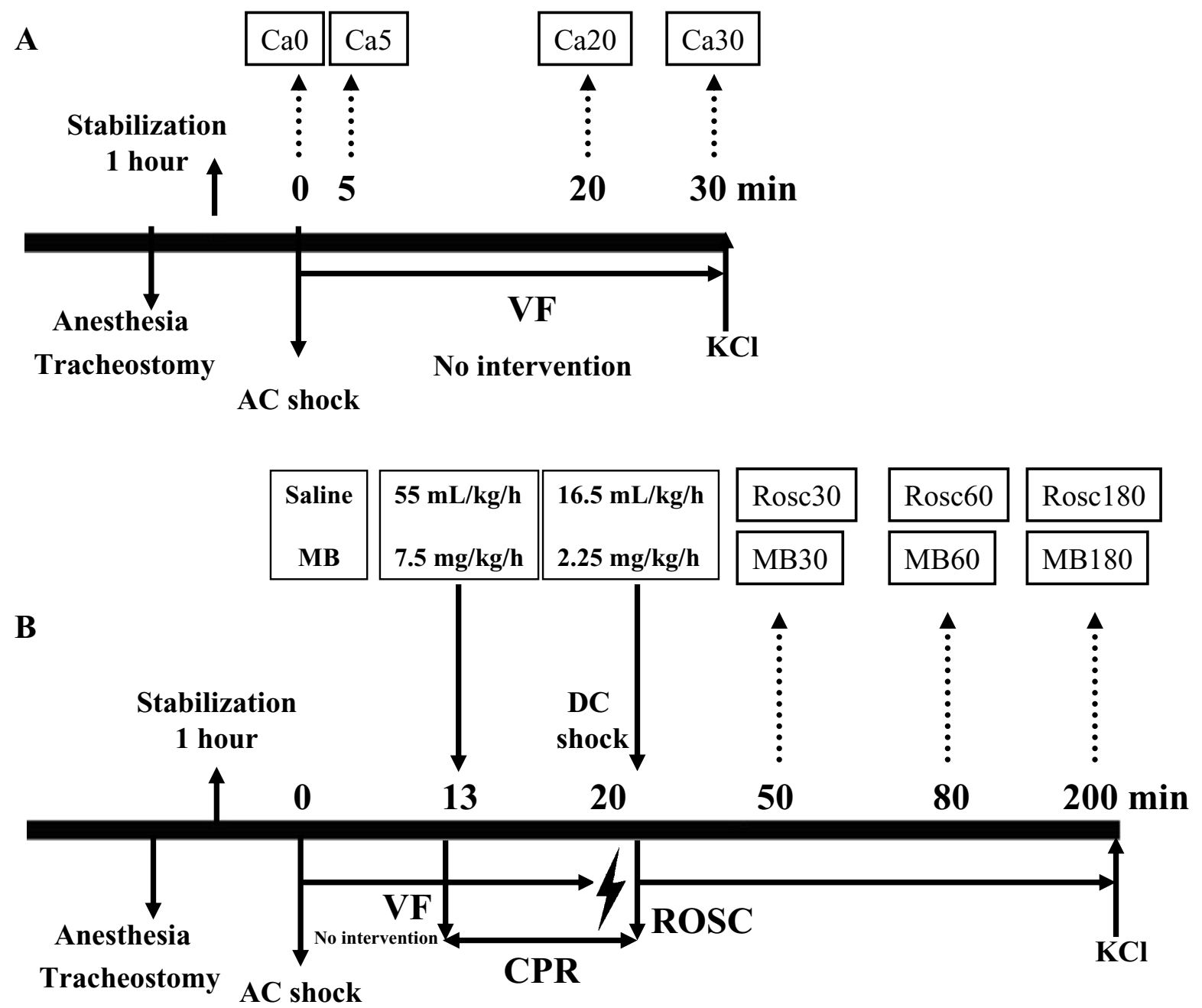

Figure 1 Experimental procedure. After stabilization for $1 \mathrm{~h}$, animals were subjected to ventricular fibrillation. They were either sacrificed with a potassium chloride injection (KCl) after 0, 5, 20 or 30 min after untreated cardiac arrest (A) or, after 12 min of cardiac arrest and 8 min of cardiopulmonary resuscitation (CPR), return of spontaneous circulation (ROSC) was carried out and animals received a saline solution (Rosc groups) or methylene blue (MB groups) before sacrifice at 30,60 and 180 min post-resuscitation (B).

Genes with raw intensity values that did not meet a minimum threshold (more than 30 in at least one of the samples) or described as absent in all 30 samples were excluded from the results. The selected probe sets were then submitted to statistical analysis to identify significant changes in gene expression. Pair-wise comparison analysis based on GCOS statistical algorithm was carried out to compare animals of the experimental group to each animal of the corresponding control group. The group means were also compared using the SAM software. By combining these 2 approaches, we obtained a list of modulated genes for each condition. The stringent criteria for the lists of genes were that the FDR values obtained with the SAM software were inferior to $5 \%$ and there were 9 significant change calls generated by GCOS. Furthermore, the lists of genes were restricted to include only genes for which expression changes were $\geq \pm 1.5$ fold. Changes which occurred 5, 20 or 30 min after cardiac arrest or 30,60 or 180 min after ROSC were analyzed using the $\mathrm{Ca} 0$ as control group. Changes after 30, 60 or $180 \mathrm{~min}$ of $\mathrm{MB}$ treatment following ROSC were analyzed using the Rosc30, Rosc60 and Rosc180 as control groups, respectively.

\section{Confirmatory Real-Time PCR analysis}

Data generated from microarrays were confirmed using real-time PCR (qPCR).

RNA was extracted as described above and then was reversely transcribed using oligo(dT) and random hex- 
amers and iScript reverse transcriptase (Bio-Rad Laboratories, USA). The qPCR was conducted on the MyiQ single-colour Real-time PCR detection system (Bio-Rad Laboratories, USA). Each reaction contained $12.5 \mu \mathrm{l} 2 \times$ IQ SYBR Green Supermix (Bio-Rad Laboratories, USA), primers and template to total volume of $25 \mu \mathrm{l}$. The thermal profile used for amplification was $95^{\circ} \mathrm{C}$ for 5 min followed by 40 cycles of $97^{\circ} \mathrm{C}$ for $15 \mathrm{sec}, 60^{\circ} \mathrm{C}$ for $15 \mathrm{sec}$, and $72^{\circ} \mathrm{C}$ for $15 \mathrm{sec}$. At the end of the amplification phase, a melting-curve analysis was carried out on the products formed. All primers were designed by Beacon Designer 5.10 (Biosoft International, Palo Alto, CA). Table 1 summarizes the information about the primers, including Genbank accession numbers.

All experiments were performed in triplicates for every sample and contained negative controls. Results were evaluated by MyiQ single-colour Real-time PCR detection system software (Bio-Rad Laboratories, USA). The expression levels for $H s p 22, H s p 27, H s p 40, H s p 70, H s p 72$, Hsp90, rgs2, cart, ndrg2 as well genes similar to dusp1, ddit3, gadd45b, nfil3, set and dhcr24 mRNA transcripts were described as the ratios of the targets normalized to the endogenous reference (sdha) and then the ratios for fold change relative to the calibrator were obtained. The calibrator was constituted from brain samples of piglets belonging to the $\mathrm{Ca} 0$ group.

\section{Results}

\section{Gene annotation}

The Affymetrix porcine genome microarray is minimally annotated. Approximately $11 \%$ of the probe sets on this array are described with gene names, posing a challenge to biological interpretation of data. Lack of annotation is likely due to the limited availability of full-length porcine cDNA sequence. To gain further information about the identity and/or function of the selected sequences which were not associated to a protein name, BLAST sequencesimilarity searches were performed. After careful verification of the resulting alignments, probe sets sharing sequence similarity with known proteins from other species were annotated as "similar to". To avoid redundancy, only gene symbols are mentioned in the text while full names are used in the figures and tables. Furthermore genes annotated "similar to" will be considered as sharing the same function as the gene they were associated with.

\section{Gene expression profiles after untreated CA}

We identified 28 transcripts as differentially expressed, of which, 21 up-regulated and 7 down-regulated (Table 2). Only 1 gene, similar to SLC3OA10 (a zinc transporter) showed a constant increase (4-fold) from 5 min to 30 min. Another zinc transporter, SLC3OA9 was found modestly increased at $30 \mathrm{~min}$ (1.5-fold). The other transcripts were found significantly changed only at 1 time point with the exception of PITRM1 which was decreased at 5 and $20 \mathrm{~min}$ and 2 uncharacterized genes which were up and down-regulated (both at 20 and $30 \mathrm{~min}$ ), respectively. Although most of the regulated transcripts showed only moderate changes, prealbumin, GNAL and beta-neoendorphin were highly up-regulated at $20 \mathrm{~min}$ (more the 10fold). Even though this data set was too small to be submitted to advanced functional analyses, a functional category could be assigned for each probe set (see Table 2).

\section{Gene expression profiles after ROSC}

Transcriptional changes for Rosc 30, 60 and 180 were analyzed using $\mathrm{Ca} 0$ as baseline. For changes specifically induced by MB treatment, MB30, 60 and 180 groups were compared to their corresponding ROSC (with saline) controls i.e. Rosc 30, 60 and 180, respectively. After gene filtering, we obtained a final list of 518 probe sets showing significant changes of expression after either ROSC or MB treatment. Manual annotations gave a total of 317 probe sets (61\%) similar to a known protein, $80(16 \%)$ identified genes and 121 (23\%) lacking any sequence similarity in any database and therefore called "unknown" (for a detailed list see Additional file 1).

We reorganized this large data set by performing hierarchical clustering (see Figure 2). The data set was split into 9 parts named cluster 1 to 9 varying in size from 2 to 207 genes. The relevance and the relationship between the clusters was studied using PCA (Figure 3A) and expression patterns (Figure 3B). The results showed 5 distinct subsets of transcripts named as cluster 1, 5, 6, 7 and 8 which contained 34, 130, 41, 205 and 99 genes, respectively. Four more diffuse and heterogeneous very small subsets (4 members or less) were not considered as valid clusters. Therefore their members were associated to the main cluster they appeared to be most similar to, based on the PCA 3D representation. "Clusters" 4 (2 genes) and 9 (3 genes) were grouped with cluster 1 (Figure 4), "cluster" 3 (4 genes) with cluster 8 (Figure 5) and "cluster" 2 (4 genes) with cluster 7 (Figure 6) while cluster 6 (Figure 7) and cluster 5 (Figure 8) remained unaffected. Relationships between the main clusters were clearly displayed by the PCA analysis: cluster 8, corresponding to genes upregulated after ROSC, opposite to cluster 1 (down-regulated after ROSC) and cluster 7, corresponding to genes induced by $\mathrm{MB}$, opposite to cluster 5 (decreased by MB) (see Figure 3A). Cluster 6 represented transcripts with an early increase of expression after ROSC and was standing by itself. Annotated genes were classified by functional category. The results for differentially expressed proteins after ROSC and by MB treatment, respectively, were summarized in Figure 9. A search for overrepresented functional classes within each cluster showed significant results only for the group formed by cluster 8 . In this group of transcripts induced after ROSC, 6 functional 
Table 1: Sequences of primers used for qRT-PCR

\begin{tabular}{|c|c|c|c|}
\hline Gene symbol & Primer sequence (5'->3') & Product & GenBank Acc* \\
\hline \multirow[t]{2}{*}{ sdha } & Forward: ACTCGCTCCTGGACCTCGTTG & $158 \mathrm{bp}$ & DQ845177 \\
\hline & Reverse: CCTTATGGTTCCGTTCGCAAATCTC & & \\
\hline \multirow[t]{2}{*}{ Hsp22 } & Forward: AGCCCTGGAAAGTGTGTGTC & $198 \mathrm{bp}$ & AY609863 \\
\hline & Reverse: GGGAAAGCGAGGCAAATACTG & & \\
\hline \multirow[t]{2}{*}{ Hsp27 } & Forward: AGGAGCGGCAGGATGAG & $100 \mathrm{bp}$ & AY574049 \\
\hline & Reverse: GACAGGGAGGAGGAGACC & & \\
\hline \multirow[t]{2}{*}{ Hsp40 } & Forward: GACCAGACCTCCAACAACATTC & $189 \mathrm{bp}$ & $\underline{\mathrm{AF} 288820}$ \\
\hline & Reverse: ATCTTTGAACACAACGGGTATGG & & \\
\hline \multirow[t]{2}{*}{ Hsp70 } & Forward: GCTCAGTGGCATACCTC & $182 \mathrm{bp}$ & $\underline{X 68213}$ \\
\hline & Reverse: CACGAACCATCCTCTCC & & \\
\hline \multirow[t]{2}{*}{ Hsp72 } & Forward: CAACAAGATCACCATCAC & $79 \mathrm{bp}$ & AY466608 \\
\hline & Reverse: CTTCTCCGCCTCCTG & & \\
\hline \multirow[t]{2}{*}{ Hsp90 } & Forward: AACCGCTCTGCTGTCTTC & $103 \mathrm{bp}$ & $\underline{\text { U94395 }}$ \\
\hline & Reverse: GTCGTCCTCATCAATACCAAG & & \\
\hline \multirow[t]{2}{*}{ Similar to dusp 1} & Forward: CAACCACAAGGCGGACATC & $200 \mathrm{bp}$ & $\underline{\text { AK232967 }}$ \\
\hline & Reverse: TGCTCCTCCTCTGCTTCAC & & \\
\hline \multirow[t]{2}{*}{ Similar to ddit4 } & Forward: AGTAAGACAGTTAAGTCAACAGTG & $91 \mathrm{bp}$ & $\underline{X M \quad 001925275}$ \\
\hline & Reverse: GCAGCGAGCACACATCC & & \\
\hline \multirow[t]{2}{*}{ Similar to gadd $45 b$} & Forward: GCTGCGATCTGAAGGTC & $102 \mathrm{bp}$ & $\underline{A K 231760}$ \\
\hline & Reverse: GCCACACGACAGTTCC & & \\
\hline \multirow[t]{2}{*}{ Similar to ddit3 } & Forward: GAACGAACGGCTCAAG & $182 \mathrm{bp}$ & CK454369 \\
\hline & Reverse: TGGCACTGGTAAGAAGG & & \\
\hline \multirow[t]{2}{*}{ rgs 2} & Forward: CCGCCGCAGATCACCACAGAG & $133 \mathrm{bp}$ & $\underline{D Q 150111}$ \\
\hline & Reverse: CCTGGCTTCCTGACTCACTAACTCC & & \\
\hline \multirow[t]{2}{*}{ Similar to $n f i l 3$} & Forward: GCCCGATCCACTCTCC & $112 \mathrm{bp}$ & $\underline{X M \quad 001928870}$ \\
\hline & Reverse: ATGGCTTTGGCTTTAATCC & & \\
\hline \multirow[t]{2}{*}{ Similar to set } & Forward: TGCCTGCCACCACCATC & $138 \mathrm{bp}$ & $\underline{\mathrm{BQ} 598788}$ \\
\hline & Reverse: CCACCAACACGGACTTCTTAC & & \\
\hline \multirow[t]{2}{*}{ cart } & Forward: CTGCTGCTGCTGCTAC & $177 \mathrm{bp}$ & AF338229 \\
\hline & Reverse: CTTCTCATAAATCGGGATACG & & \\
\hline \multirow[t]{2}{*}{ Similar to $d h c r 24$} & Forward: AGTGTATGGTGTGTG & $116 \mathrm{bp}$ & CF360734 \\
\hline & Reverse: GTTCTGGACAGTAGG & & \\
\hline \multirow[t]{2}{*}{$n d r g 2$} & Forward: CCCGTGTTCCCTTTGG & $151 \mathrm{bp}$ & $\underline{\text { DQ985169 }}$ \\
\hline & Reverse: GGTGACTAAGAGCATATCG & & \\
\hline
\end{tabular}

${ }^{*}$ GeneBank accession number at www.ncbi.nlm.nih.gov

classes corresponding to response to stress ( $\mathrm{p}<0.001)$, regulation of transferase activity $(\mathrm{p}=0.001)$, regulation of protein kinase activity $(\mathrm{p}=0.001)$, apoptosis/type I programmed cell death $(\mathrm{p}=0.034)$, activation of mitogenactivated protein (MAP) kinase kinase kinase $(\mathrm{p}=0.044)$ and programmed cell death $(\mathrm{p}=0.044)$ were overrepresented. A list of the processes affected after ROSC and/or by $\mathrm{MB}$ (addressed in the discussion) can be found in Additional file 2.

\section{Replication of gene expression profiles by RT-qPCR}

Validation of differentially expressed genes according to the microarray results was conducted by RT-qPCR. We selected genes with different expression patterns and the 
Table 2: Differentially expressed genes after $5 \mathrm{~min}$ (Ca5), $20 \mathrm{~min}$ (Ca20) and $30 \mathrm{~min}$ (ca30) of untreated CA

\begin{tabular}{|c|c|c|c|c|c|c|}
\hline \multirow[t]{2}{*}{ Regulation } & \multirow[t]{2}{*}{ Known Function } & \multirow[t]{2}{*}{ Probe Set } & \multirow[t]{2}{*}{ Gene Products } & \multicolumn{3}{|c|}{ Fold change } \\
\hline & & & & $\mathrm{Ca5}$ & $\mathrm{Ca20}$ & Ca30 \\
\hline \multirow[t]{21}{*}{ Up } & Transcription & Ssc.9200.1.A1_at & $\begin{array}{l}\text { similar to } Z C C H C 12, \text { Zinc finger } C C H C \\
\text { domain-containing protein } 12\end{array}$ & 1.3 & $2.1^{*}$ & 1.3 \\
\hline & Transcription & Ssc.2132.1.S1_a_at & $\begin{array}{l}\text { similar to RPS6KA5 ribosomal protein } \\
\text { S6 kinase alpha-5 }\end{array}$ & 0.8 & $2.3^{*}$ & 1.0 \\
\hline & Transcription & Ssc.22527.1.A1_at & $\begin{array}{l}\text { similar to homeobox protein } P B X 3 \text {, } \\
\text { Pre-B-cell leukemia transcription } \\
\text { factor } 3 .\end{array}$ & 0.9 & $2.5^{*}$ & 1.3 \\
\hline & $\begin{array}{l}\text { Signal } \\
\text { transduction }\end{array}$ & Ssc.14404.1.A1_at & $\begin{array}{l}\text { HTR2C, 5-hydroxytryptamine } \\
\text { (serotonin) receptor } 2 C\end{array}$ & 1.1 & $4.6^{*}$ & 1.5 \\
\hline & Transport & Ssc.640.1.S1_at & $\pi R$, Transthyretin (Prealbumin) & 27 & $2789^{*}$ & 2.6 \\
\hline & Cation transport & Ssc.3850.1.S1_at & similar to $N N A T$, neuronatin & 1.4 & $1.9^{*}$ & 1.4 \\
\hline & $\begin{array}{l}\text { Potassium } \\
\text { transport }\end{array}$ & Ssc.6932.1.A1_at & $\begin{array}{l}\text { similar to DPP10, inactive dipeptidyl } \\
\text { peptidase } 10\end{array}$ & 1.3 & 1.1 & $1.5^{*}$ \\
\hline & Zinc transport & Ssc.7040.1.A1_at & $\begin{array}{l}\text { similar to SLC } 30 A 9 \text {, solute carrier } \\
\text { family } 30 \text { member } 9\end{array}$ & 1.4 & 1.1 & $1.5^{*}$ \\
\hline & Zinc transport & Ssc.17849.1.A1_at & $\begin{array}{l}\text { similar to SLC } 30 A 10 \text {, solute carrier } \\
\text { family } 30 \text { member } 10\end{array}$ & $4.0^{*}$ & $4.5^{*}$ & $4.7^{*}$ \\
\hline & $\begin{array}{l}\text { Calcium- } \\
\text { mediated } \\
\text { signalling }\end{array}$ & Ssc.29371.1.A1_at & $\begin{array}{l}\text { similar to GNAL guanine nucleotide- } \\
\text { binding protein G(olf) subunit alpha }\end{array}$ & 1.6 & $16.5^{*}$ & 1.1 \\
\hline & $\begin{array}{l}\text { Calcium- } \\
\text { mediated } \\
\text { signalling }\end{array}$ & Ssc.19549.1.S1_at & $\begin{array}{l}\text { similar to } N E C A B 1 \text {, Neuronal calcium- } \\
\text { binding protein } 1\end{array}$ & 1.5 & 1.0 & $2.0^{*}$ \\
\hline & $\begin{array}{l}\text { Calcium- } \\
\text { mediated } \\
\text { signalling }\end{array}$ & Ssc.3649.1.A1_at & $\begin{array}{l}\text { similar to } R C A N 3 \text { regulator of } \\
\text { calcineurin } 3 \text { (calcipressin-3) }\end{array}$ & 1.1 & $1.5^{*}$ & 1.0 \\
\hline & Opioid peptide & Ssc.121.1.S1_at & PDYN, Beta-neoendorphin-dynorphin & 6.2 & $14.2^{*}$ & 1.4 \\
\hline & Stress response & Ssc.7903.1.A1_at & $\begin{array}{l}\text { similar to HSPA13, Heat shock } 70 \mathrm{kDa} \\
\text { protein } 13 \text { (stress } 70 \text { protein } \\
\text { chaperone microsome-associated } 60 \\
\text { kDa protein) }\end{array}$ & 1.3 & 0.9 & $2.0^{*}$ \\
\hline & Neurogenesis & Ssc.19425.1.A1_at & $\begin{array}{l}\text { similar to MAPT, microtubule- } \\
\text { associated protein tau }\end{array}$ & $1.7^{*}$ & 1.0 & 1.2 \\
\hline & $\begin{array}{l}\text { Nucleic acid } \\
\text { metabolism }\end{array}$ & Ssc.6238.2.S1_at & $\begin{array}{l}\text { similar to } A K 3, \text { GTP:AMP } \\
\text { phosphotransferase mitochondrial } \\
\text { (adenylate kinase 3) }\end{array}$ & 1.3 & 1.1 & $1.7^{*}$ \\
\hline & Not determined & Ssc.12504.1.A1_at & similar to protein $F A M 14 A$ & 0.9 & $2.0^{*}$ & 0.9 \\
\hline & Not determined & Ssc.30063.1.A1_at & unknown & $2.4^{*}$ & 1.0 & 1.0 \\
\hline & Not determined & Ssc.29510.1.A1_at & unknown & 1.6 & 1.4 & $2.1^{*}$ \\
\hline & Not determined & Ssc.21096.1.S1_at & unknown & 1.3 & $3.6^{*}$ & $4.5^{*}$ \\
\hline & Not determined & Ssc.31095.1.A1_at & unknown & 1.3 & $2.0^{*}$ & 0.9 \\
\hline \multirow[t]{2}{*}{ Down } & Transcription & Ssc.19152.1.S1_at & $\begin{array}{l}\text { similar to CPSF7, cleavage and } \\
\text { polyadenylation specificity factor } 7\end{array}$ & 0.8 & 0.8 & $0.6^{*}$ \\
\hline & $\begin{array}{l}\text { Signal } \\
\text { transduction }\end{array}$ & Ssc.13752.1.S1_at & $\begin{array}{l}\text { similar to } P I K 3 R 1, \\
\text { phosphatidylinositol 3-kinase p85 } \\
\text { regulatory subunit alpha }\end{array}$ & 0.7 & $0.3^{*}$ & 0.8 \\
\hline
\end{tabular}


Table 2: Differentially expressed genes after $5 \mathrm{~min}$ (Ca5), $20 \mathrm{~min}$ (Ca20) and $30 \mathrm{~min}$ (ca30) of untreated CA (Continued)

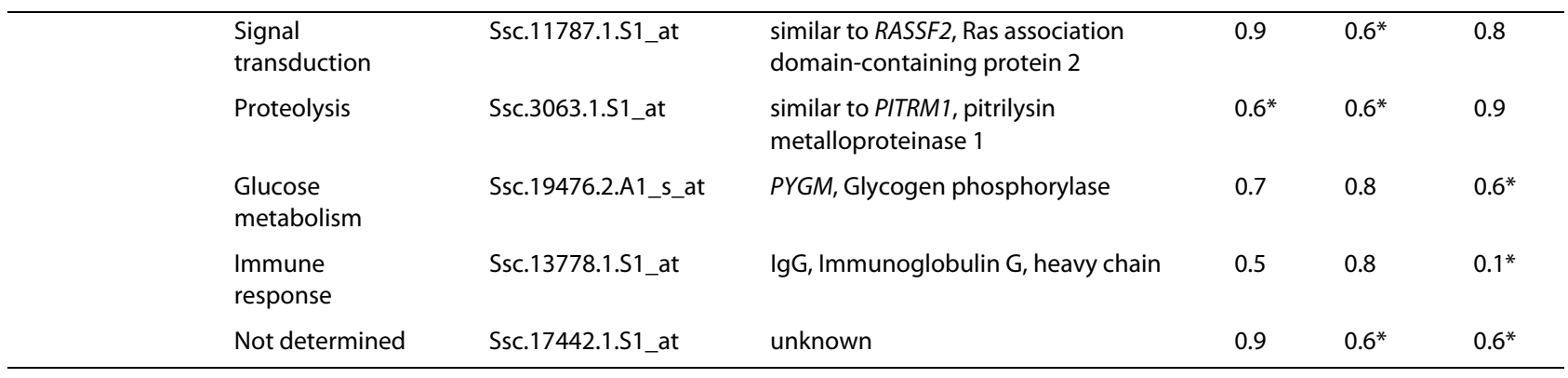

results showed a good correlation with the findings from microarrays (Figure 10)

\section{Discussion}

\section{Effects of cardiac arrest/global ischemia}

Interruption of blood flow after CA limits the delivery of oxygen and glucose to neurons causing ATP reduction which has numerous consequences including neurotoxicity, DNA damage, and production of free radicals [23]. In our model, we found only 28 significantly differentially expressed transcripts in total after global ischemia. Among the moderately up-regulated genes, it is noteworthy that 7 transcripts affected by ischemia belonged to ion transport and calcium signalling functions as it is well known that one of the first consequences of ischemiainduced apoptosis is a disruption of ionic gradients across membranes with increase in extracellular potassium and influx of sodium, chloride and calcium into the cells. Interestingly our list included 2 zinc transporters: SLC30A9 (ZNT9) and SLC30A10 (ZNT10). These findings are in line with an earlier study showing that another member of the SLC30 family, ZNT1, was induced after transient forebrain ischemia in the Gerbil [24]. The SLC30 proteins are CDF (cation diffusion facilitatator) proteins and plasma membrane efflux transporters [25]. The mechanism of transport for many CDF proteins appears to be via zinc/H + or $\mathrm{K}+$ antiports. Therefore, despite their name, CDF proteins do not serve as diffusion facilitators but rather as secondary active transporters, using the gradient of other ions to drive the transport of zinc [26]. Identification of ZNT9 and ZNT10 as ischemia-induced genes adds therefore to the growing evidence suggesting that the role of zinc efflux transporters in cellular zinc homeostasis may be particularly important in postischemic neuronal death where high levels of zinc are accumulated by neurons [27].

\section{Effects of ROSC/reperfusion}

Cardiac arrest and CPR elicit global brain ischemia and reperfusion causing immediate and delayed cell death. I/ $\mathrm{R}$ injury results in oxidative stress leading to further generation of free radicals. This in turn activates numerous major signalling pathways, in particular through changes in gene expression which influence the survival or death of the cells.

The use of microarrays has been applied to study the effects of permanent or transient ischemia on total brain or distinct regions in rodent models but, to our knowledge, this is the first time that a genome-wide transcript profiling study is undertaken in porcine brain to study the effect of I/R. Our results showed that 141 genes were induced and only 39 were repressed after ROSC. Such an imbalance between up- and down-regulated genes could be due to a technical bias. Yet it is in agreement with a recent report where the authors monitored the genomic response to global ischemia and reperfusion in the rat brain and concluded that the ischemia/reperfusion response of the rat brain is therefore an active process [28]. A functional analysis of the clusters revealed that apoptosis/programmed cell death and stress response (34\% of all induced genes) were overrepresented among the genes up-regulated after ROSC. Among them we found proteins belonging to the caspase-dependent apoptotic pathway, p53 and mitogen-activated protein kinase pathways, playing a pivotal role in stress and apoptosis. Consistent with findings in rodent, heat shock proteins are among the most prominently upregulated genes after the ischemic insult $[29,30]$. Overall our gene lists are in line with previous microarray studies monitoring cerebral ischemic insult [28-34] including proteins such as ICAM1 , a main actor for the regulation of ischemia-induced injury since its inhibition induces neuroprotection after I/ $\mathrm{R}$ injury [35,36]; VEGFA as a main indicator for brain ischemia [37]; IFRD1, an early gene stimulating p53 and up-regulating iNOS after oxidative stress [38]; inducible HMOX1 and constitutive HMOX2, two rate-limiting enzymes for the catabolism of the prooxidant heme $[39,40]$ and CHOP. a main marker of ER stress $[41,42]$.

\section{Effects of MB treatment}

One of the responses to cerebral ischemia is an increase in the production of $\mathrm{NO}$, catalyzed by nitric oxide synthase (NOS) expression. There has been increasing evidence that neuronal nitric oxide synthase (nNOS)- 


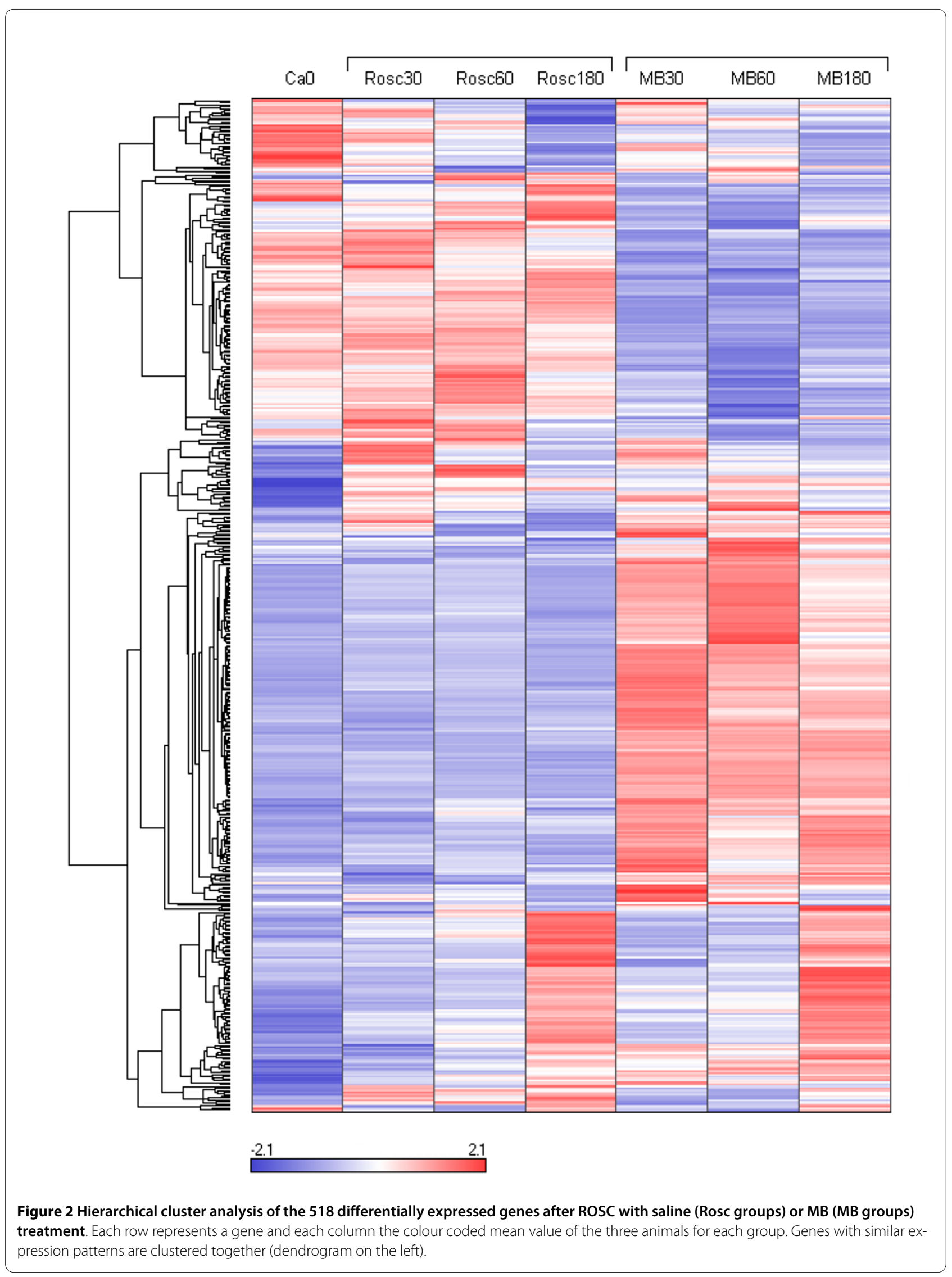


A

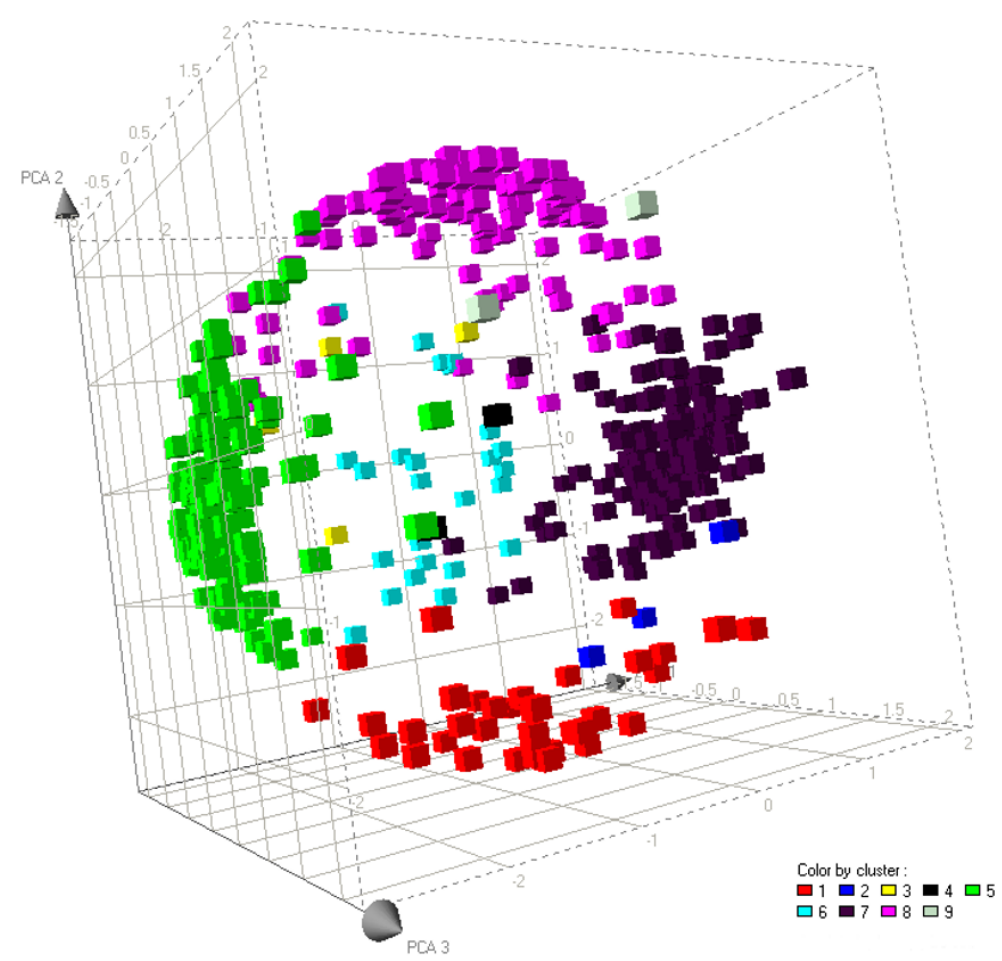

B

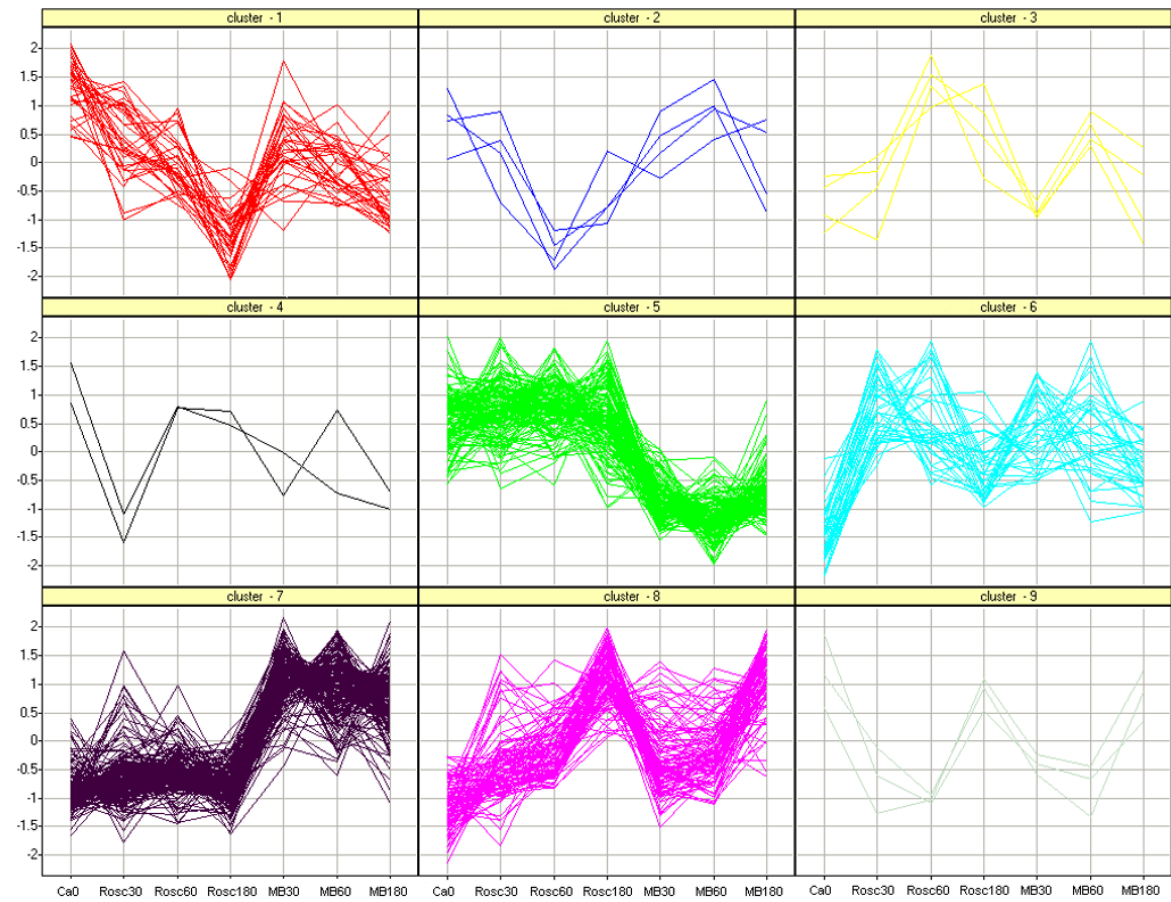

Figure 3 Principle component analysis (A) and scatter plot of the expression profiles (B) defined by the 9 clusters generated by hierarchical clustering. Each cluster can be easily identified by its associated colour. 


\section{A}

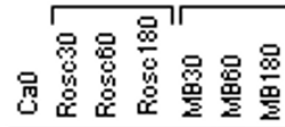

\begin{tabular}{|l|l|l|l|l|l|l|l}
\hline & & & & & & - unknown \\
\hline
\end{tabular}

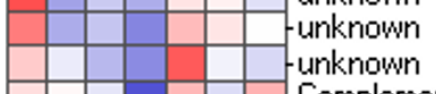

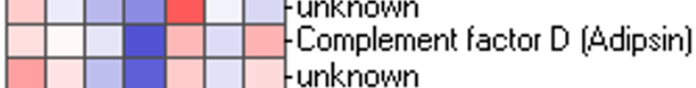

\begin{tabular}{|l|l|l}
\hline & & - similar to dystrobrevin alpha \\
\hline & & -unknown \\
& -imilar to $\mathrm{PZY}$ purinoceptor 12
\end{tabular}

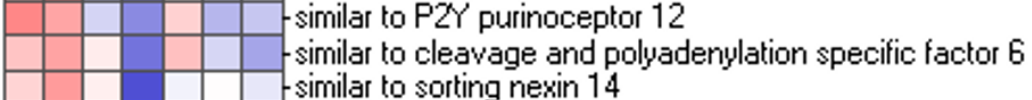

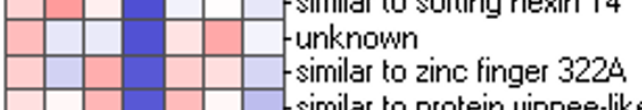

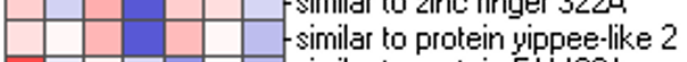

- similar to protein FAM38A

-similar to syntaxin-binding protein 5

-unknown

-similar to Ribonucleases P/MRP protein subunit POP1

-unknown

-unknown

-unknown

-unknown

-unknown

- similar to Brain-specific angiogenesis inhibitor 3

- similar to Zinc finger protein 251

- similar to type II iodothyronine deiodinase

- similar to poly $(A)$ binding protein, nuclear 1

-Splicing factor arginine/serine-rich 11

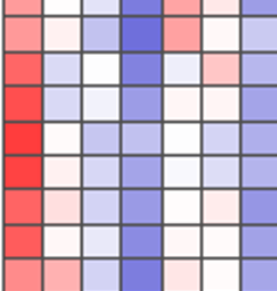

-Similar to Calcium-dependent secretion activator 2

-LIM domain transcription factor LMO4

Similar to Synaptosomal-associated $25 \mathrm{kD}$ a protein

- similar to cytoplasmic dynein 1 intermediate chain $1 / 2$

Similar to Regulating synaptic membrane exocytosis protein 2

unknown

similar to zinc and ring finger 3

Q

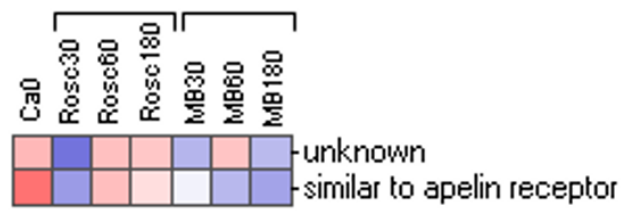

$\mathrm{C}$

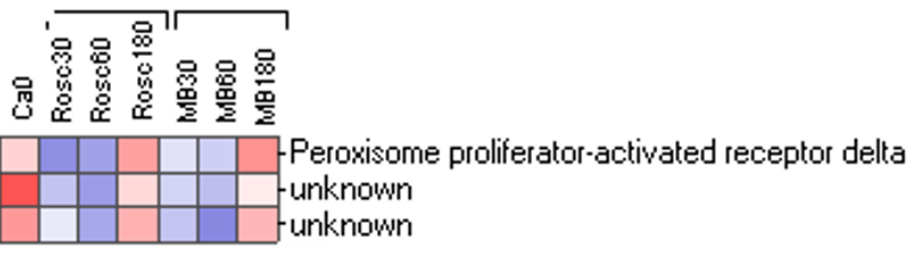




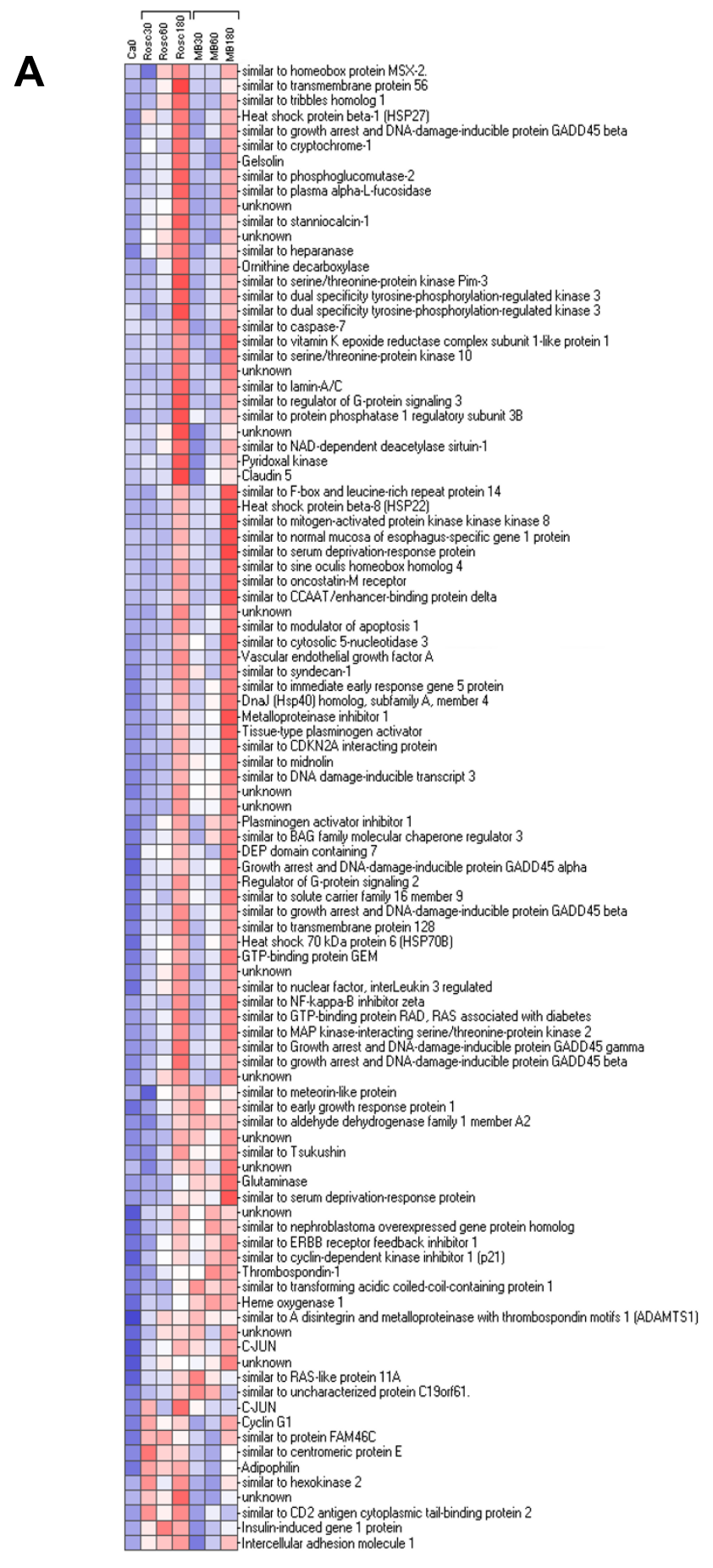

B

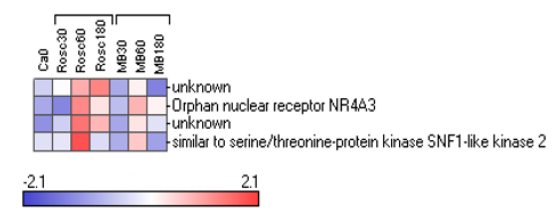

Figure 5 Hierarchical clustering of two subsets of genes segregating in cluster 8 (A), "cluster" 3 (B) and for which expression levels increased after ROSC 
A
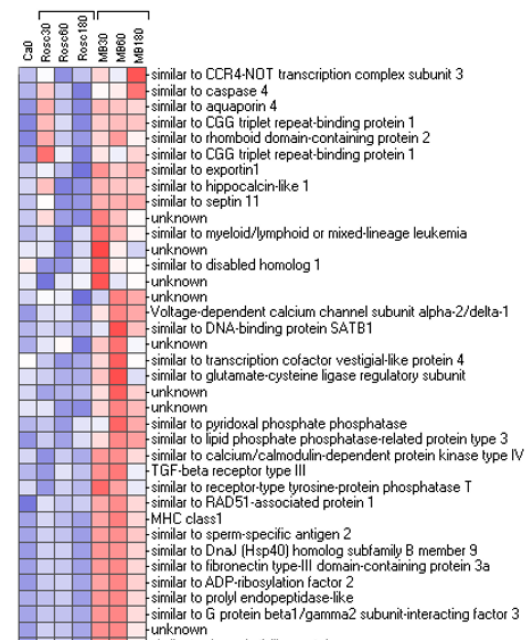
similar to prolyl endopeptidase-like
similar to $G$ protein beta $1 / g a m m a$ - - similar to dynamin-1.1-like protein - similar to bone morphogenetic protein receptor type-2 - similat to vacuolar ATP synthase subunit B

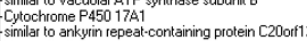

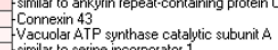
- - - imilarlat to serine incorporator 1 -Glycine receptor subunitit beta
-similar to glia maturation factor bets - similar to glia maturation factor beta -Sodum/potassium.transporting ATPase
- similat to glyoxalaseI
- similar to F. ox $/$ WD repeat protein 11

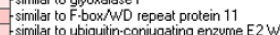
- similar to ubiquitin-conjugating enzyme $E 2 W$
-similar to MKI67 FHA domain-interacting nucleolar phosphoprotein - similar to ankyrin3 3 .
-Heat shock protein HSP 90-alph - Heat shock protein HSP 90-alpha
-similar to ormithine decarboxylase antizyme inhibitor - similar to ornithine decarboxylase antizyme
- similar to 24 -dehydrocholesterol reductase
- similar to vesicle-traficicking protein $\mathrm{SEC} C 22 \mathrm{~b}$ - Metarlarloproteinase inhibitor 3

- - - simkniawn to palmitoyltransferase ZDHHC17 -similar to gamma-aminobuturic acid receptor-associated protein-like 1 - similar to progressivive ankulylosicis protein homolog - similar to

- - Tuberous sclerosis 1 protein -similar to calcium channel, voltage-dependent, alpha $2 /$ delta subunit 1 similar to brain acid soluble protein 1 - similar to cell division cycle 2-like 6 - similar to muscleblind-like protein 1 - - - -imkiniar to Zinc finger protein 91 homolog -similat to zinc finger protein 335 -similar to muscleblind-1.ke protein

unknown
similar to Kelch domain.containing protein 2 -similar to microtubule associated protein 16 -unknown

-sinknilar to probable RNA-binding protein 25 -similar to ring finger protein 103
-imilar to syntaxin 5

- similar to syntaxin 5 -

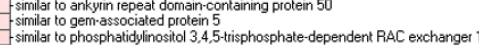
-similar to phosphatidylinositol $3,4,5$-trisphosphate-dependent
similar to nucleosome assembly protein 1 -like 1 -similar to nucleosome assembly protein 1 1.ike 1
-similar to PEST proteolytic signal-containing nuclear protein -similar to chordin-like protein

- - - Siminiart to transcciption factor AP.2 alpha -similar to calcium/calmodulin-dependent serine protein kinase -similar to DNA damage-binding protein 1 . . -similar to cytochrome c oxidase assembly protein COX15 homolog similar to solute carrier family 30 member 3
similar to glucose-6.-phosphate translocase - similar to recombining binding protein suppressor of hailless
- similar to $A D P$.tibosylation factor-like 15

MHC class II SLA-DRB2.2D

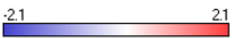

B

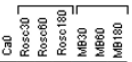

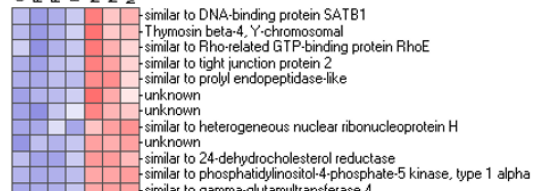

similar to 24 -dehydrocholesterol reductase
similar to phosphatidylinositol-4-phosphas

5 kinase, type 1 alpha

similar to prefoldin subunit 6

- similar to apoptosis regulatory protein Siva
- similar to CCR4-NOT transcription complex, subunit 7

-similar to zinc finger and BTB domain-containing protein 47

similar to ring finger and $\mathrm{CCCH}$-type zinc finger domain-containing protein 2

-similar to ornithine decarboxylase antizyme 2

- similar to geranylgeranyl pyrophosphate synthetase
similar to growth factor receptor-bound protein 2 .

- simlar to growth lactor receptor-bound protein 2 .

simlar to tinucleotide repeat-containing gene 4 protein
- similar to gamma-aminobutyric acid receptor-associated protein-like 1

265 proteasome non-ATPase regulatory subunit 4

- similar to DNA.directed RNA polymerasel subunit RPA49

imilar to phosphatidylinosito-binding clathrin assembly protein

unknown
similar to trinucleotide repeat-containing protein 15

-similar to transmembrane protein 131

simiar to signal tecognitlase 3 .

similar to aloha-internexin

-similar to cold shock domain-containing protein E1

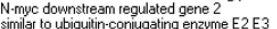

unknown
similar to coiled-coil domain-containing protein 1094

similat to coled-coil domain-containing protein
similat to ubiquitininconiugating enzyme $22 S$

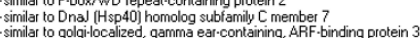

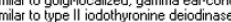

-unknown

(imin to probable global transcription activator SNFaI similar to non-impinted in Prader- W/Wili/Angelman syndrome region protein 1 - similar to lysophospholipase

Decorin

simlar to cyclin-L2
similar to exocyst complex component5

similar to exocyst complex component 5
E3 ubiquitin-protein ligase CBL

unknown
similar to yeast nucleotide excision repair MMS19 homolog

unknown timilat to twisted gastrulation protein homolog 1

imilar to ELAV (Embryonic lethal, abnormal vision, Drosophila).1-ke 4

imilar to sarcolembing

Sliceosome RNA helicase BATT

-unknown
similar to TBC1 domain family member $10 \mathrm{~A}$.

mhoma-associated antigen 5

similar to integin alpha-k

similat to microtubule associated protein 16

similar to ER lumen protein retaining receptor 2

-unknown

similar to WD repeat and SOCS box-containing

-unknown

C.4 methylsterol oxidase

simmlar to EIbb2-interacting protein
similar to methyltransferase 11 domain containing 1

similar to serine/threonine-protein kinase tousled-1ik

unknown

unknown
similar to dual specificity protein phosphatase 6

unknown

similar to neurotimin

similar to vacuolar protein sorting-associated protein 16 homolog

unknown

Cocaine. and amphetamine-regulated transcipt protein
Receptor for gonadotropie releasing hormone II (GnRH II)

-unknown

-unknown
similar to BTB/POZ domain-containing protein 3

simular to BTB/POZ domain-containing prot
Kruepel-ike factor 4

JUNB

'similar to tyrosine 3-monooxygenase/tryptophan 5 -monooxygenase activation protein, zet: imilar to lg-lambda

simlar to protein enabled homolog

similar to $\$ 100$ calcium-binding protein $A 8$ 


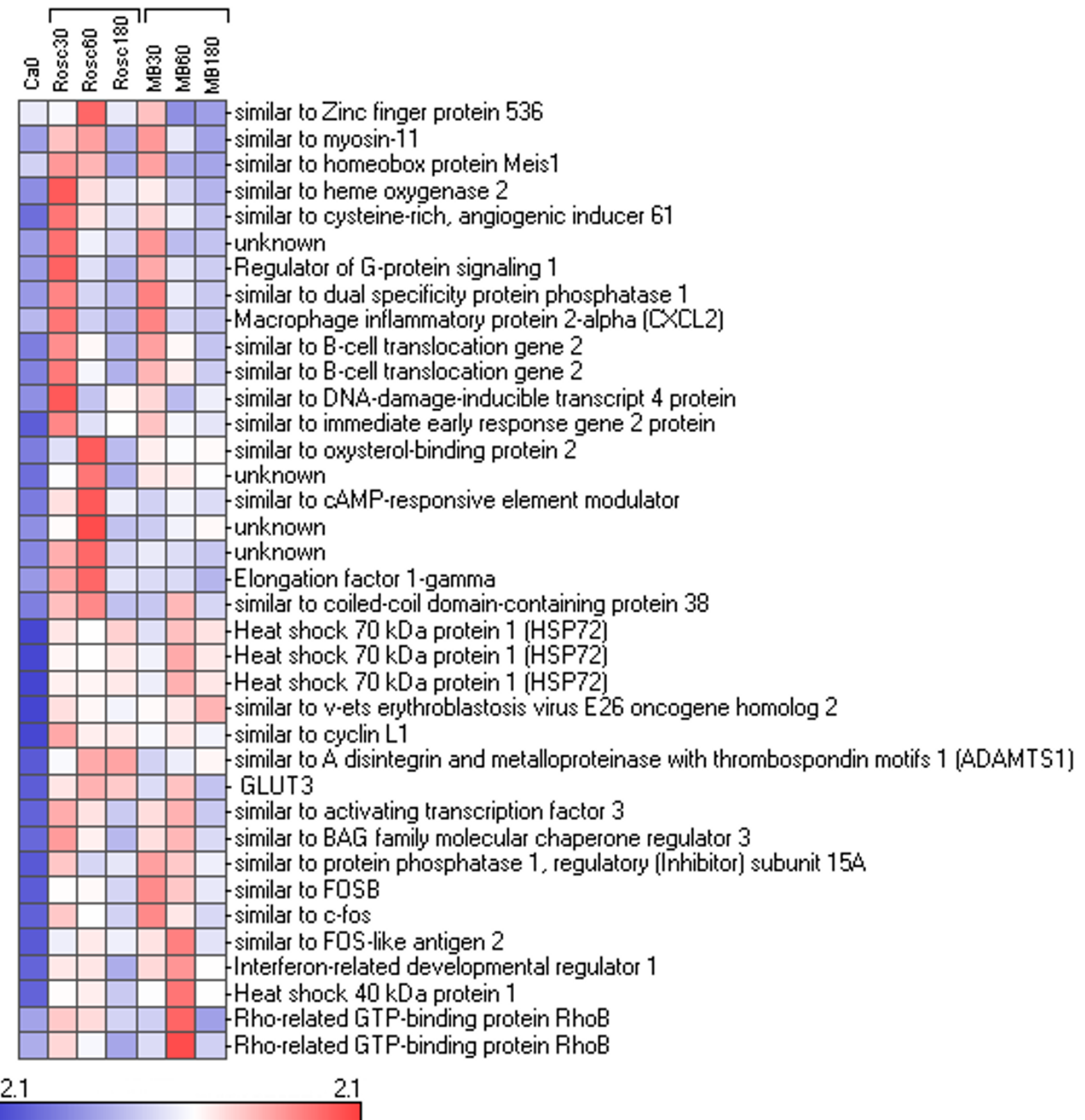

Figure 7 Hierarchical clustering of a subset of genes segregating in cluster 6 and for which expression levels were early induced after ROSC.

induced NO is an important mediator in ischemic brain injury [43]. Methylene blue (MB) exerts an antioxidant effect by binding and inactivating the action of NO [44], blocking the soluble guanylate cyclase [45] - the primary receptor for NO - as well as inhibiting Nitric Oxide Synthase (NOS) [46]. Although transcriptional levels of NOS did not show any changes after treatment by MB in our study, we have previously reported that NOS enzymes were regulated by $\mathrm{MB}$ at the protein level, in porcine brain, already after 30 min (Miclescu et al., submitted). These results concur with the conclusion that NOS enzymes are preferentially regulated post-transcriptionally, thus allowing a more rapid adaptation of the enzyme activity to cellular stress variations [47]. As could be expected, we identified the sGC transcript in the set of genes regulated by MB together with HSP90, a chaperone forming a complex with both sGC and endothelial nitric oxide synthase (eNOS) for the modulation of NO produc- 


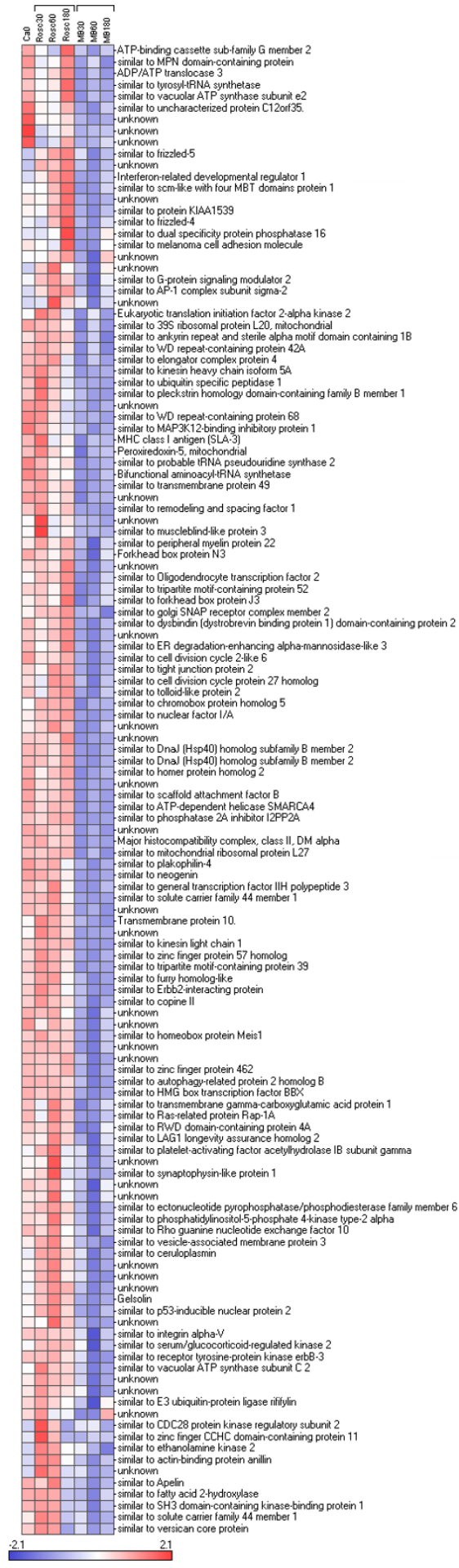

Figure 8 Hierarchical clustering of a subset of genes segregating in cluster 5 and for which expression levels were early decreased after MB treatment.
A

Genes regulated after ROSC

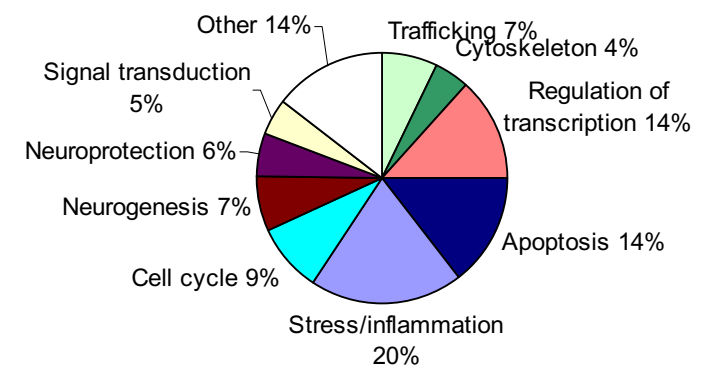

B

\section{Genes regulated by MB}

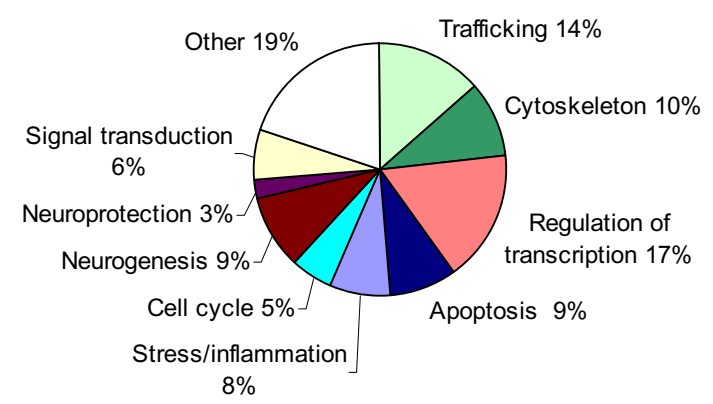

Figure 9 Functional analysis of genes regulated after ROSC (A) and genes affected by MB treatment (B). Proportion of differentially expressed genes in different functional categories. One gene can be assigned several functions and therefore belong to more than one category.

tion [48]. Although the modulation of cGMP/NO pathway is considered the most significant effect of $M B$, recent studies indicate that it has multiple cellular and molecular targets.

\section{Inhibition of apoptosis}

A number of anti-apoptotic genes were found stimulated by MB. Some of them exert their effect via inhibition of caspases: DHCR24 (seladin-1), which protects cells from oxidative stress by reducing caspase 3 activity [49,50]; PIP5K1, decreasing activated caspases [51]; ELAVL4, an actor in both neuron-specific RNA processing (for example protecting $\mathrm{p} 21 \mathrm{mRNA}$ from decay) and inhibition of mitochondria-dependent apoptosis [52,53]. Others were identified as antagonists of the MAPK/p53 apoptotic pathways: RND3, a pro-survival p53 target gene that inhibits ROCK I-mediated apoptosis in response to stress and participates to neurite extension [54]; CSDE1, which 

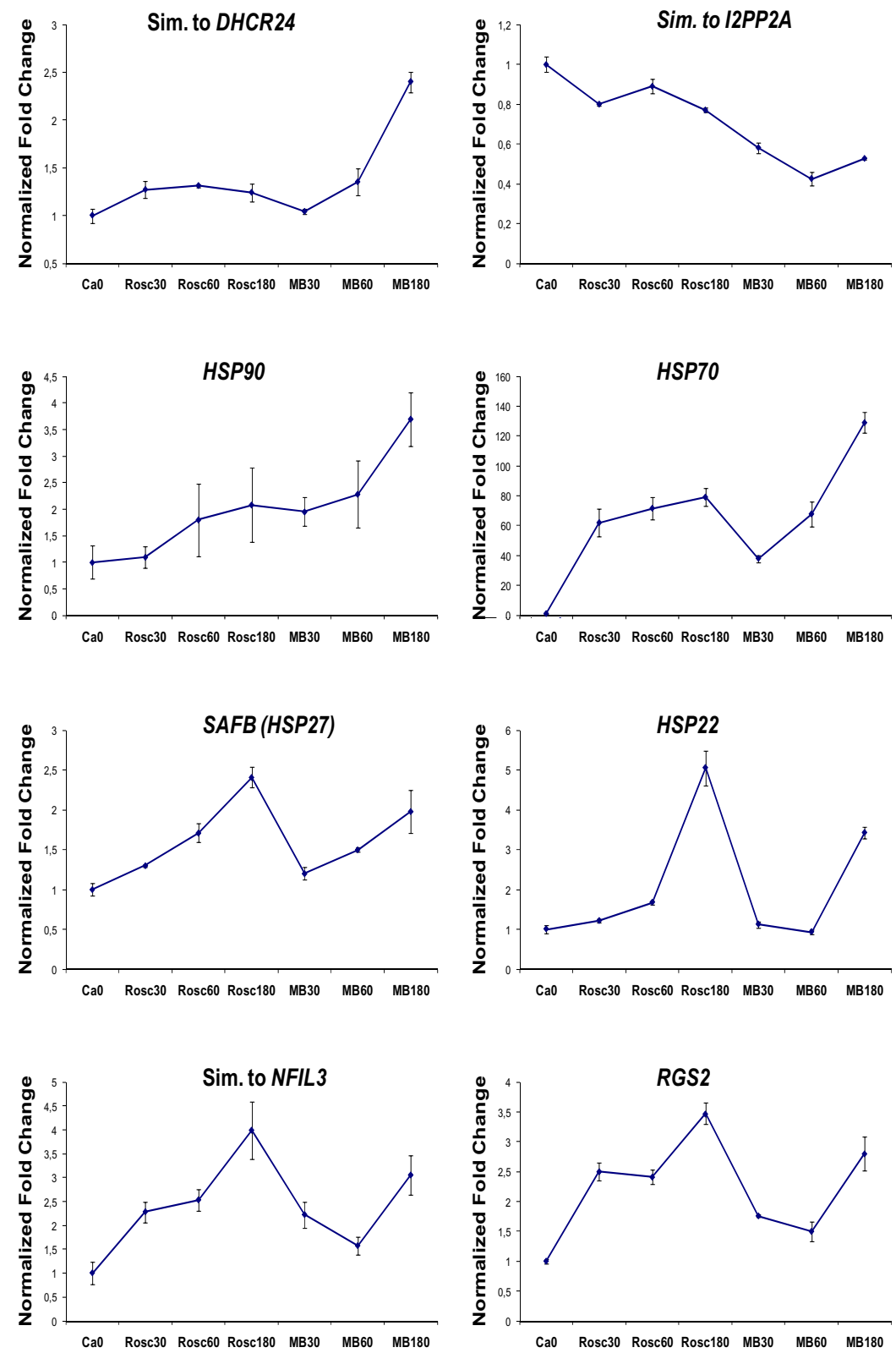

Ca0 Rosc30 Rosc60 Rosc180 MB30 MB60 MB180

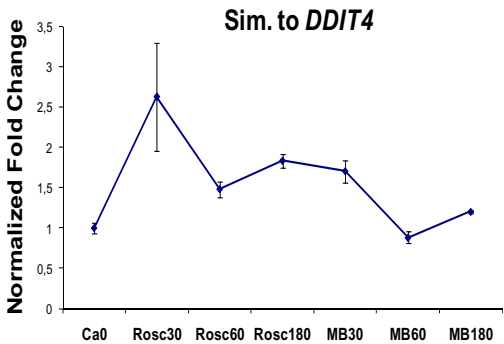

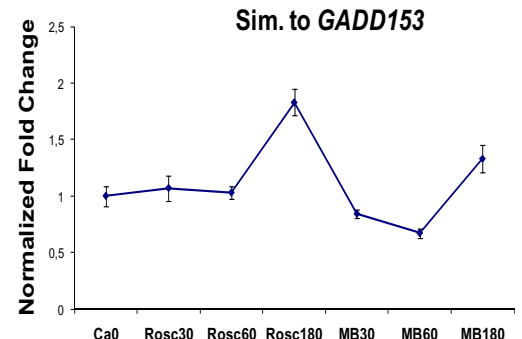
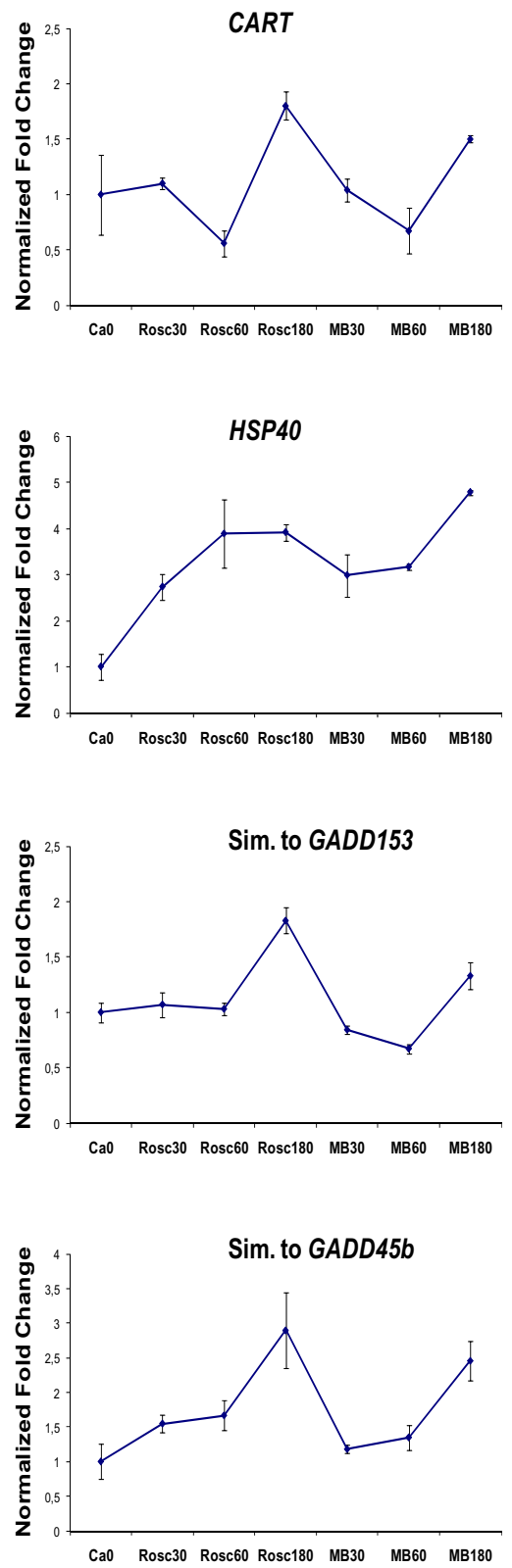

Ca0 Rosc30 Rosc60 Rosc180 MB30 MB60 MB180

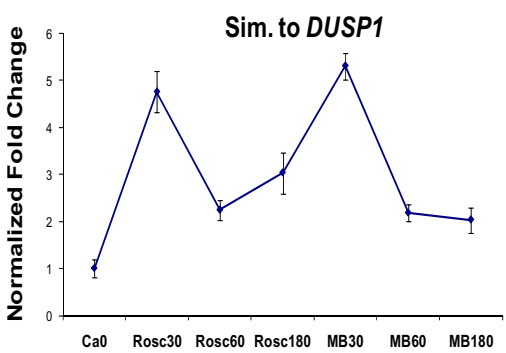

Ca0 Rosc30 Rosc60 Rosc180 MB30 MB60 MB180

Figure 10 Real-time qPCR analysis of genes that showed a significant differential expression in the microarray study. The genes were selected based on relevance to ischemia/reperfusion injury pathophysiology. Data are shown as means (fold change) of normalized ratios of three biological replicas (y-axis). Error bars represent standard error of the mean (SEM). 
decreases p53/GADD45g/caspase3 transcription [55]; DDB1, a pro-survival p53 target involved in protein degradation [56]; DUSP6, a MAPK phosphatase which inactivates ERK [57]; YWHAZ, which supports cell survival by antagonizing apoptotic proteins and has a neuroprotective role as p38 MAPK inhibitor $[58,59]$; as well as CAMK4, a key protein involved in oxidative stress which promotes neuronal survival and inhibits apoptosis [60]. Although the anti-apoptotic effect of MB appeared to be mostly caused by stimulation of specific transcripts, the repression of the following genes participated to the overall protective effect of MB: SMARCA4, a chromatin remodelling factor and an apoptotic p53 target [61]; NEO which acquires its pro-apoptotic activity when cleaved by caspases [62]; TMEM49, a stress-induced protein that promotes formation of intracellular vacuoles involved in autophagy [63]; SET (I2PP2A) mediating neuronal apoptosis [64]; SLC25A6 which participates in the formation of the permeability transition pore complex (PTPC) responsible for the release of mitochondrial signals [65]; and SAFB, an apoptosis marker [66].

\section{ER stress}

Upon reperfusion after even a short period of transient global cerebral ischemia, protein synthesis is severely suppressed [67,68]. Ischemia-induced suppression of protein synthesis, which is initiated by activation of kinases phosphorylating the initiation factor 2 (eIF2a), has been attributed to ER dysfunction [69]. Our results showed that eIF2AK2 (PKR) one of the kinases that specifically phosphorylates eIF2a and therefore inhibits translation [70], was repressed by $\mathrm{MB}$ together with EDEM3, a protein enhancing the ER-associated degradation (ERAD) [71]. In addition, DNAJB9, an ER chaperone suppressing cell death and induced by ER stress [72] was also induced by MB. These results suggest a potential counteracting effect of $\mathrm{MB}$ on the shutdown of translation by ER stress.

\section{Vesicle transport}

Disruption of the cytoskeleton induced by apoptosis causes a depolymerization of microtubules followed by Golgi fragmentation and secretory membrane traffic arrest [73,74]. In the Golgi network, proteins are sorted and segregated into transport vesicles to be targeted to subcellular compartments or released such as neurotransmitters. Our observations suggested that vesicle trafficking might be affected by MB since proteins which mediate transport between ER and Golgi such as SEC22b, STX5, KDELR2 and ERGIC1 [75,76,78] and VPS16 and GGA3 between Golgi and the endosomes [79,80] were up-regulated. On the other hand, proteins such as: VAMP3, a vesicle-associated membrane protein involved in regulating membrane traffic; AP1S2, modulating the dynamics of the cytoskeleton [81]; and GOSR2 involved in transport of proteins from the cis/medial-Golgi to the trans-Golgi network [75]; were down-regulated by MB.

\section{Neurogenesis}

Microtubules, a major component of the cytoskeleton which is damaged by ischemia, are crucial for intracellular transport and neurogenesis/neural regeneration. For example, the principle mechanisms involved in neurite extension and axonal pathfinding rely upon the reorganization of cytoskeletal elements induced by microtubuleassociated proteins (MAPs) [82]. Our results showed changes in a number of microtubule-related proteins induced by MB: GABARAPL1 and MAP1B, two members of the MAP family; EXOC5 mediating the targeting of post-Golgi secretory vesicles and stimulating neurite outgrowth [83]; NIPA1 regulating synaptic growth and axonal microtubules [84]; INA, an intermediate filament protein involved in the morphogenesis of neurons; CAMK4 and SEMA6A, both involved in regulation of microtubule dynamics [85-87]; and SEPT11, which regulates microtubule stability through interaction with MAP4 [88]. In contrast, 2 microtubule subunits, the kinesins KIF5A and KLC1, were inhibited by MB. In addition to stimulation of the microtubule networks, $\mathrm{MB}$ induced proteins important for brain repair or regeneration such as: BASP1, TM4SF1, NT, SMARCA1 and RND3, which all promote neurite outgrowth $[54,89-92]$; RUFY3, a prosurvival gene implicated in the formation of a single axon in developing neurons [93]; GMFB which stimulates neural regeneration; SC4MOL, involved in brain repair [94]; CASK which plays a role in synaptogenesis [95]; as well as PAFAH1B2, DAB1 and PREX1 involved in brain cell migration [96-98]. The effect of $\mathrm{MB}$ on neurogenesis included also the inhibition of OLIG2, a repressor of neurogenesis [99] and two axon-guidance regulating proteins, NEO and NFIA $[62,100]$.

\section{Neuroprotection}

$\mathrm{MB}$ induced genes known to have a neuroprotective effect such as: CX43, the primary component protein in astrocytic gap junctions playing multiple roles in the mitigation of apoptotic neuronal damage in cerebral ischemia[101,102];. THBD, which activates the antiinflammatory and cytoprotective activated protein $\mathrm{C}$ (APC) thus leading to promotion of neovascularization and neurogenesis in the post-ischemic brain [103]; AQP4, a neuroprotective water-specific channel, osmoreceptor regulating water flow in central nervous system $[104,105]$; and CART, an intriguing peptide which protects brain from damage both through ERK activation in ischemic stroke [106] and potential preservation of mitochondrial function and prevention of energy failure after I/R injury [107].

\section{Conclusions}

All these findings suggest that $\mathrm{MB}$ exerts neuroprotection by regulation of the expression of soluble guanylate cyclase and diverse biological processes from inhibition of apoptosis and reversal of the shutdown of translation 
to restoration of functional cellular trafficking and activation of brain repair/regeneration genes as well as induction of critical neuroprotective proteins. Therefore they support that MB could be a valuable intervention and should be investigated as a therapeutic agent against neural damage associated with $\mathrm{I} / \mathrm{R}$ injury induced by cardiac arrest.

\section{Additional material}

Additional file 1 Affymetrix probe set identifiers and gene symbols and annotations for all genes found significantly differentially expressed after return of spontaneous circulation and/or treatment with methylene blue. Annotations are arranged in the order they appear in each cluster (from top to bottom). table.

Additional file 2 Processes and Proteins affected by ROSC and MB respectively. table.

\section{Competing interests}

The authors declare that they have no competing interests.

\section{Authors' contributions}

CM performed the experimental work and drafted the manuscript. LW performed the surgery on the animals and participated in experimental design and data evaluation. Both authors read and approved the final version of the manuscript.

\section{Acknowledgements}

This study was supported by The Laerdal Foundation for Acute Medicine. We are grateful to the core facility for Bioinformatics and Expression Analysis (BEA, Karolinska Institute) and to the Uppsala Array Platform for kindly allowing us to run our microarrays using their Affymetrix systems.

\section{Author Details}

Department of Surgical Sciences/Anaesthesiology and Intensive Care Medicine, Uppsala University Hospital, SE-751 85 Uppsala, Sweden

Received: 15 February 2010 Accepted: 1 July 2010

Published: 1 July 2010

\section{References}

1. 2005 American Heart Association Guidelines for Cardiopulmonary Resuscitation and Emergency Cardiovascular Care Part 7.5: postresuscitation support. Circulation 2005, 112(24 Suppl):IV84-IV88

2. Safar $P$, Behringer W, Bottiger BW, Sterz F: Cerebral resuscitation potentials for cardiac arrest. Crit Care Med 2002, 30(4 Suppl):S140-144.

3. Negovsky VA, Gurvitch AM: Post-resuscitation disease--a new nosological entity. Its reality and significance. Resuscitation 1995, 30(1):23-27.

4. Nolan JP, Neumar RW, Adrie C, Aibiki M, Berg RA, Bottiger BW, Callaway C, Clark RS, Geocadin RG, Jauch EC, et al:: Post-cardiac arrest syndrome: Epidemiology pathophysiology, treatment and prognostication $\mathrm{A}$ Scientific Statement from the International Liaison Committee on Resuscitation; the American Heart Association Emergency Cardiovascular Care Committee; the Council on Cardiovascular Surgery and Anesthesia; the Council on Cardiopulmonary Perioperative, and Critical Care; the Council on Clinical Cardiology; the Council on Stroke. Resuscitation 2008, 79(3):350-379.

5. van Alem AP, Waalewijn RA, Koster RW, de Vos R: Assessment of quality of life and cognitive function after out-of-hospital cardiac arrest with successful resuscitation. Am J Cardiol 2004, 93(2):131-135.

6. Kellum MJ, Kennedy KW, Barney R, Keilhauer FA, Bellino M, Zuercher M, Ewy GA: Cardiocerebral resuscitation improves neurologically intact survival of patients with out-of-hospital cardiac arrest. Ann Emerg Med 2008, 52(3):244-252.

7. Nolan JP, Deakin CD, Soar J, Bottiger BW, Smith G: European Resuscitation Council guidelines for resuscitation 2005. Section 4. Adult advanced life support. Resuscitation 2005, 67(Suppl 1):S39-86.
8. Herlitz J, Castren M, Friberg H, Nolan J, Skrifvars M, Sunde K, Steen PA: Post resuscitation care: what are the therapeutic alternatives and what do we know? Resuscitation 2006, 69(1):15-22.

9. Hannon J, Bossone C, Wade C: Normal physiological values for conscious pigs used in biomedical research. Lab Anim Sci 1990, 40(3):293-298.

10. Hannon JP, Bossone CA: Cardiovascular and pulmonary effects of morphine in conscious pigs. Am J Physiol 1991, 261 (5 Pt 2):R1286-1293.

11. Hanneman SK, Clubb FJ Jr, McKay K, Costas G: Feasibility of a porcine adult intensive care model. Comp Med 2004, 54(1):36-43.

12. Lind NM, Moustgaard A, Jelsing J, Vajta G, Cumming P, Hansen AK: The use of pigs in neuroscience: modeling brain disorders. Neurosci Biobehav Rev 2007, 31(5):728-751.

13. Fries M, Nolte K, Demir F, Kottmann K, Timper A, Coburn M, Weis J, Rossaint R: Neurocognitive performance after cardiopulmonary resuscitation in pigs. Crit Care Med 2008, 36(3):842-847.

14. Peter C, Hongwan D, Kupfer A, Lauterburg BH: Pharmacokinetics and organ distribution of intravenous and oral methylene blue. Eur J Clin Pharmacol 2000, 56(3):247-250.

15. Kupfer A, Aeschlimann C, Cerny T: Methylene blue and the neurotoxic mechanisms of ifosfamide encephalopathy. Eur J Clin Pharmacol 1996, 50(4):249-252.

16. Wainwright $M$, Crossley KB: Methylene Blue--a therapeutic dye for all seasons? J Chemother 2002, 14(5):431-443.

17. Naylor GJ, Martin B, Hopwood SE, Watson Y: A two-year double-blind crossover trial of the prophylactic effect of methylene blue in manicdepressive psychosis. Biological Psychiatry 1986, 21(10):915-920.

18. Wiklund L, Basu S, Miclescu A, Wiklund P, Ronquist G, Sharma HS: Neuroand cardioprotective effects of blockade of nitric oxide action by administration of methylene blue. Ann N Y Acad Sci 2007, 1122:231-244.

19. Miclescu A, Basu S, Wiklund L: Cardio-cerebral and metabolic effects of methylene blue in hypertonic sodium lactate during experimental cardiopulmonary resuscitation. Resuscitation 2007, 75(1):88-97.

20. Kelner M, Bagnell R, Hale B, NM A: Potential of methylene blue to block oxygen radical generation in reperfusion injury. Basic Life Sci 1988, 49:895-898

21. Miclescu A, Basu S, Wiklund L: Methylene blue added to a hypertonichyperoncotic solution increases short-term survival in experimental cardiac arrest. Crit Care Med 2006, 34(11):2806-2813.

22. Tusher VG, Tibshirani R, Chu G: Significance analysis of microarrays applied to the ionizing radiation response. Proc Natl Acad Sci USA 2001, 98(9):5116-5121.

23. Lipton P: Ischemic cell death in brain neurons. Physiol Rev 1999, 79(4):1431-1568.

24. Tsuda M, Imaizumi K, Katayama T, Kitagawa K, Wanaka A, Tohyama M, Takagi T: Expression of zinc transporter gene ZnT-1, is induced after transient forebrain ischemia in the gerbil. J Neurosci 1997, 17(17):6678-6684

25. Seve M, Chimienti F, Devergnas S, Favier A: In silico identification and expression of SLC30 family genes: an expressed sequence tag data mining strategy for the characterization of zinc transporters' tissue expression. BMC Genomics 2004, 5(1):32.

26. Guffanti AA, Wei Y, Rood SV, Krulwich TA: An antiport mechanism for a member of the cation diffusion facilitator family: divalent cations efflux in exchange for $\mathrm{K}+$ and $\mathrm{H}+$. Mol Microbiol 2002, 45(1):145-153.

27. Galasso SL, Dyck RH: The role of zinc in cerebral ischemia. Mol Med 2007, 13(7-8):380-387.

28. Buttner F, Cordes C, Gerlach F, Heimann A, Alessandri B, Luxemburger U, Tureci O, Hankeln T, Kempski O, Burmester T: Genomic response of the rat brain to global ischemia and reperfusion. Brain Res 2009, 1252:1-14.

29. Schmidt-Kastner R, Zhang B, Belayev L, Khoutorova L, Amin R, Busto R, Ginsberg MD: DNA microarray analysis of cortical gene expression during early recirculation after focal brain ischemia in rat. Brain Res Mol Brain Res 2002, 108(1-2):81-93.

30. Tang Y, Lu A, Aronow BJ, Wagner KR, Sharp FR: Genomic responses of the brain to ischemic stroke intracerebral haemorrhage kainate seizures hypoglycemia, and hypoxia. Eur J Neurosci 2002, 15(12):1937-1952.

31. Lu XC, Williams AJ, Yao C, Berti R, Hartings JA, Whipple R, Vahey MT, Polavarapu RG, Woller KL, Tortella FC, et al: Microarray analysis of acute and delayed gene expression profile in rats after focal ischemic brain injury and reperfusion. J Neurosci Res 2004, 77(6):843-857. 
32. Sonninen R, Virtanen T, Sivenius J, Jolkkonen J: Gene expression profiling in the hippocampus of rats subjected to focal cerebral ischemia and enriched environment housing. Restor Neurol Neurosci 2006 24(1):17-23.

33. Kawahara N, Wang Y, Mukasa A, Furuya K, Shimizu T, Hamakubo T, Aburatani H, Kodama T, Kirino T: Genome-wide gene expression analysis for induced ischemic tolerance and delayed neuronal death following transient global ischemia in rats. $J$ Cereb Blood Flow Metab 2004, 24(2):212-223.

34. Jin K, Mao XO, Eshoo MW, Nagayama T, Minami M, Simon RP, Greenberg DA: Microarray analysis of hippocampal gene expression in global cerebral ischemia. Ann Neurol 2001, 50(1):93-103.

35. Frijns CJ, Kappelle LJ: Inflammatory cell adhesion molecules in ischemic cerebrovascular disease. Stroke 2002, 33(8):2115-2122.

36. Cheng $Y$, Zhang HT, Sun L, Guo S, Ouyang S, Zhang Y, Xu J: Involvement of cell adhesion molecules in polydatin protection of brain tissues from ischemia-reperfusion injury. Brain Res 2006, 1110(1):193-200.

37. Hayashi T, Abe K, Suzuki H, Itoyama Y: Rapid induction of vascular endothelial growth factor gene expression after transient middle cerebral artery occlusion in rats. Stroke 1997, 28(10):2039-2044.

38. Marroquin CE, Wai PY, Kuo PC, Guo H: Redox-mediated upregulation of hepatocyte iNOS transcription requires coactivator PC4. Surgery 2005, 138(1):93-99.

39. Dore S, Takahashi M, Ferris CD, Zakhary R, Hester LD, Guastella D, Snyder $\mathrm{SH}$ : Bilirubin, formed by activation of heme oxygenase-2, protects neurons against oxidative stress injury. Proc Natl Acad Sci USA 1999, 96(5):2445-2450.

40. Saleem S, Zhuang H, Biswal S, Christen Y, Dore S: Ginkgo biloba extract neuroprotective action is dependent on heme oxygenase 1 in ischemic reperfusion brain injury. Stroke 2008, 39(12):3389-3396.

41. Ma Y, Brewer JW, Diehl JA, Hendershot LM: Two distinct stress signaling pathways converge upon the CHOP promoter during the mammalian unfolded protein response. J Mol Biol 2002, 318(5):1351-1365.

42. Tajiri S, Oyadomari S, Yano S, Morioka M, Gotoh T, Hamada Jl, Ushio Y, Mori M: Ischemia-induced neuronal cell death is mediated by the endoplasmic reticulum stress pathway involving CHOP. Cell Death Differ 2004, 11(4):403-415.

43. Jiang MH, Kaku T, Hada J, Hayashi Y: Different effects of eNOS and nNOS inhibition on transient forebrain ischemia. Brain Res 2002, 946(1):139-147.

44. Wolin MS, Cherry PD, Rodenburg JM, Messina EJ, Kaley G: Methylene blue inhibits vasodilation of skeletal muscle arterioles to acetylcholine and nitric oxide via the extracellular generation of superoxide anion. J Pharmacol Exp Ther 1990, 254(3):872-876.

45. Gruetter CA, Kadowitz PJ, Ignarro LJ: Methylene blue inhibits coronary arterial relaxation and guanylate cyclase activation by nitroglycerin sodium nitrite and amyl nitrite. Can J Physiol Pharmacol 1981, 59(2):150-156.

46. Mayer B, Brunner F, Schmidt K: Inhibition of nitric oxide synthesis by methylene blue. Biochem Pharmacol 1993, 45(2):367-374.

47. Geller DA, Billiar TR: Molecular biology of nitric oxide synthases. Cancer Metastasis Rev 1998, 17(1):7-23.

48. Venema RC, Venema VJ, Ju H, Harris MB, Snead C, Jilling T, Dimitropoulou C, Maragoudakis ME, Catravas JD: Novel complexes of guanylate cyclase with heat shock protein 90 and nitric oxide synthase. Am J Physiol Heart Circ Physio/ 2003, 285(2):H69-678.

49. Peri A, Serio M: Neuroprotective effects of the Alzheimer's diseaserelated gene seladin-1. J Mol Endocrinol 2008, 41(5):251-261.

50. Kuehnle K, Ledesma MD, Kalvodova L, Smith AE, Crameri A, SkaanesBrunner F, Thelen KM, Kulic L, Lutjohann D, Heppner FL, et al: Agedependent Increase in Desmosterol Restores DRM Formation and Membrane-related Functions in Cholesterol-free DHCR24(-/-) Mice. Neurochem Res 2009, 34(6):1167-1182.

51. Halstead JR, van Rheenen J, Snel MH, Meeuws S, Mohammed S, D'Santos CS, Heck AJ, Jalink K, Divecha N: A role for PtdIns(4,5)P2 and PIP5Kalpha in regulating stress-induced apoptosis. Curr Biol 2006, 16(18):1850-1856.

52. Joseph B, Orlian M, Furneaux H: p21 (waf1) mRNA contains a conserved element in its 3'-untranslated region that is bound by the Elav-like mRNA-stabilizing proteins. J Biol Chem 1998, 273(32):20511-20516.

53. De Giorgio R, Bovara M, Barbara G, Canossa M, Sarnelli G, De Ponti F, Stanghellini V, Tonini M, Cappello S, Pagnotta E, et al:: Anti-HuD-induced neuronal apoptosis underlying paraneoplastic gut dysmotility. Gastroenterology 2003, 125(1):70-79.

54. Chardin P: Function and regulation of Rnd proteins. Nat Rev Mol Cell Biol 2006, 7(1):54-62

55. Dormoy-Raclet V, Markovits J, Malato Y, Huet S, Lagarde P, Montaudon D, Jacquemin-Sablon A, Jacquemin-Sablon H: Unr, a cytoplasmic RNAbinding protein with cold-shock domains is involved in control of apoptosis in ES and HuH7 cells. Oncogene 2007, 26(18):2595-2605

56. Cang Y, Zhang J, Nicholas SA, Bastien J, Li B, Zhou P, Goff SP: Deletion of DDB1 in mouse brain and lens leads to $p 53$-dependent elimination of proliferating cells. Cell 2006, 127(5):929-940.

57. Muda M, Theodosiou A, Rodrigues N, Boschert U, Camps M, Gillieron C, Davies K, Ashworth A, Arkinstall S: The dual specificity phosphatases M3/ 6 and MKP-3 are highly selective for inactivation of distinct mitogenactivated protein kinases. J Biol Chem 1996, 271(44):27205-27208.

58. Ichijo H, Nishida E, Irie K, ten Dijke P, Saitoh M, Moriguchi T, Takagi M, Matsumoto K, Miyazono K, Gotoh Y: Induction of apoptosis by ASK1, a mammalian MAPKKK that activates SAPK/JNK and p38 signaling pathways. Science 1997, 275(5296):90-94.

59. Chen XQ, Fung YW, YU AC: Association of 14-3-3gamma and phosphorylated bad attenuates injury in ischemic astrocytes. $J$ Cereb Blood Flow Metab 2005, 25(3):338-347.

60. See V, Boutillier AL, Bito H, Loeffler JP: Calcium/calmodulin-dependent protein kinase type IV (CaMKIV) inhibits apoptosis induced by potassium deprivation in cerebellar granule neurons. FASEB J 2001, 15(1):134-144

61. Xu Y, Zhang J, Chen $X$ : The activity of $p 53$ is differentially regulated by Brm- and Brg1-containing SWI/SNF chromatin remodeling complexes. $J$ Biol Chem 2007, 282(52):37429-37435.

62. Matsunaga E, Tauszig-Delamasure S, Monnier PP, Mueller BK, Strittmatter SM, Mehlen P, Chedotal A: RGM and its receptor neogenin regulate neuronal survival. Nat Cell Biol 2004, 6(8):749-755.

63. Ropolo A, Grasso D, Pardo R, Sacchetti ML, Archange C, Lo Re A, Seux M, Nowak J, Gonzalez CD, lovanna JL, et al:: The pancreatitis-induced vacuole membrane protein 1 triggers autophagy in mammalian cells. J Biol Chem 2007, 282(51):37124-37133.

64. Madeira A, Pommet JM, Prochiantz A, Allinquant B: SET protein (TAF1beta, 12PP2A) is involved in neuronal apoptosis induced by an amyloid precursor protein cytoplasmic subdomain. FASEB J 2005, 19(13):1905-1907

65. Zamora M, Granell M, Mampel T, Vinas O: Adenine nucleotide translocase 3 (ANT3) overexpression induces apoptosis in cultured cells. FEBS Lett 2004, 563(1-3):155-160.

66. Lee YB, Colley S, Norman M, Biamonti G, Uney JB: SAFB re-distribution marks steps of the apoptotic process. Exp Cell Res 2007, 313(18):3914-3923.

67. Bodsch W, Takahashi K, Barbier A, Ophoff BG, Hossmann KA: Cerebral protein synthesis and ischemia. Prog Brain Res 1985, 63:197-210.

68. Thilmann R, Xie Y, Kleihues P, Kiessling M: Persistent inhibition of protein synthesis precedes delayed neuronal death in postischemic gerbil hippocampus. Acta Neuropathol 1986, 71(1-2):88-93.

69. Paschen W: Shutdown of translation: lethal or protective? Unfolded protein response versus apoptosis. J Cereb Blood Flow Metab 2003, 23(7):773-779.

70. Raven JF, Koromilas AE: PERK and PKR: old kinases learn new tricks. Cell Cycle 2008, 7(9):1146-1150

71. Oda Y, Hosokawa N, Wada I, Nagata K: EDEM as an acceptor of terminally misfolded glycoproteins released from calnexin. Science 2003, 299(5611):1394-1397.

72. Kurisu J, Honma A, Miyajima H, Kondo S, Okumura M, Imaizumi K: MDG1/ ERdj4, an ER-resident DnaJ family member suppresses cell death induced by ER stress. Genes Cells 2003, 8(2):189-202.

73. Lane JD, Lucocq J, Pryde J, Barr FA, Woodman PG, Allan VJ, Lowe M: Caspase-mediated cleavage of the stacking protein GRASP65 is required for Golgi fragmentation during apoptosis. J Cell Bio/ 2002, 156(3):495-509.

74. Lowe M, Lane JD, Woodman PG, Allan VJ: Caspase-mediated cleavage of syntaxin 5 and giantin accompanies inhibition of secretory traffic during apoptosis. J Cell Sci 2004, 117(Pt 7):1139-1150.

75. Xu D, Joglekar AP, Williams AL, Hay JC: Subunit structure of a mammalian ER/Golgi SNARE complex. J Biol Chem 2000, 275(50):39631-39639. 
76. Rowe T, Dascher C, Bannykh S, Plutner H, Balch WE: Role of vesicleassociated syntaxin 5 in the assembly of pre-Golgi intermediates. Science 1998, 279(5351):696-700.

77. Martinez-Menarguez JA, Geuze HJ, Slot JW, Klumperman J: Vesicular tubular clusters between the ER and Golgi mediate concentration of soluble secretory proteins by exclusion from COPI-coated vesicles. Cell 1999, 98(1):81-90

78. Tang BL: Emerging aspects of membrane traffic in neuronal dendrite growth. Biochim Biophys Acta 2008, 1783(2):169-176.

79. Kim BY, Ueda M, Kominami E, Akagawa K, Kohsaka S, Akazawa C: Identification of mouse Vps16 and biochemical characterization of mammalian class C Vps complex. Biochem Biophys Res Commun 2003, 311(3):577-582.

80. Kakhlon O, Sakya P, Larijani B, Watson R, Tooze SA: GGA function is required for maturation of neuroendocrine secretory granules. $E M B O \mathrm{~J}$ 2006, 25(8):1590-1602.

81. Orzech E, Livshits L, Leyt J, Okhrimenko H, Reich V, Cohen S, Weiss A, Melamed-Book N, Lebendiker M, Altschuler Y, et al.: Interactions between adaptor protein-1 of the clathrin coat and microtubules via type 1a microtubule-associated proteins. J Biol Chem 2001, 276(33):31340-31348

82. Gonzalez-Billault C, Owen R, Gordon-Weeks PR, Avila J: Microtubuleassociated protein $1 \mathrm{~B}$ is involved in the initial stages of axonogenesis in peripheral nervous system cultured neurons. Brain Res 2002, 943(1):56-67.

83. Vega IE, Hsu SC: The exocyst complex associates with microtubules to mediate vesicle targeting and neurite outgrowth. J Neurosci 2001 , 21(11):3839-3848

84. Wang X, Shaw WR, Tsang HT, Reid E, O'Kane CJ: Drosophila spichthyin inhibits BMP signaling and regulates synaptic growth and axonal microtubules. Nat Neurosci 2007, 10(2):177-185

85. Melander Gradin H, Marklund U, Larsson N, Chatila TA, Gullberg M: Regulation of microtubule dynamics by $\mathrm{Ca} 2+/$ calmodulin-dependent kinase IV/Gr-dependent phosphorylation of oncoprotein 18. Mol Cell Biol 1997, 17(6):3459-3467.

86. Prislei S, Mozzetti S, Filippetti F, De Donato M, Raspaglio G, Cicchillitti L, Scambia G, Ferlini C: From plasma membrane to cytoskeleton: a novel function for semaphorin 6A. Mol Cancer Ther 2008, 7(1):233-241.

87. Suto F, Ito K, Uemura M, Shimizu M, Shinkawa Y, Sanbo M, Shinoda T, Tsuboi M, Takashima S, Yagi T, et al:: Plexin-a4 mediates axon-repulsive activities of both secreted and transmembrane semaphorins and plays roles in nerve fiber guidance. J Neurosci 2005, 25(14):3628-3637.

88. Kremer BE, Haystead T, Macara IG: Mammalian septins regulate microtubule stability through interaction with the microtubulebinding protein MAP4. Mol Biol Cell 2005, 16(10):4648-4659.

89. Frey D, LauX T, Xu L, Schneider C, Caroni P: Shared and unique roles of CAP23 and GAP43 in actin regulation neurite outgrowth and anatomical plasticity. J Cell Biol 2000, 149(7):1443-1454.

90. Stipp CS, Hemler ME: Transmembrane-4-superfamily proteins CD15 and CD81 associate with alpha 3 beta 1 integrin and selectively contribute to alpha 3 beta 1-dependent neurite outgrowth. J Cell Sci 2000, 113(Pt 11):1871-1882.

91. Gil OD, Zanazzi G, Struyk AF, Salzer JL: Neurotrimin mediates bifunctional effects on neurite outgrowth via homophilic and heterophilic interactions. J Neurosci 1998, 18(22):9312-9325.

92. Barak O, Lazzaro MA, Lane WS, Speicher DW, Picketts DJ, Shiekhattar R Isolation of human NURF: a regulator of Engrailed gene expression. EMBO J 2003, 22(22):6089-6100.

93. Mori T, Wada T, Suzuki T, Kubota Y, Inagaki N: Singar1, a novel RUN domain-containing protein suppresses formation of surplus axons for neuronal polarity. J Biol Chem 2007, 282(27):19884-19893.

94. Uwabe K, Gahara Y, Yamada H, Miyake T, Kitamura T: Identification and characterization of a novel gene (neurorep 1) expressed in nerve cells and up-regulated after axotomy. Neuroscience 1997, 80(2):501-509.

95. Samuels BA, Hsueh YP, Shu T, Liang H, Tseng HC, Hong CJ, Su SC, Volker J, Neve RL, Yue DT, et al.: Cdk5 promotes synaptogenesis by regulating the subcellular distribution of the MAGUK family member CASK. Neuron 2007, 56(5):823-837.

96. Hattori M, Adachi H, Tsujimoto M, Arai H, Inoue K: Miller-Dieker lissencephaly gene encodes a subunit of brain platelet-activating factor acetylhydrolase [corrected]. Nature 1994, 370(6486):216-218.
97. Assadi AH, Zhang G, Beffert U, McNeil RS, Renfro AL, Niu S, Quattrocchi CC, Antalffy BA, Sheldon M, Armstrong DD, et al: Interaction of reelin signaling and Lis1 in brain development. Nat Genet 2003, 35(3):270-276

98. Yoshizawa M, Kawauchi T, Sone M, Nishimura YV, Terao M, Chihama K Nabeshima Y, Hoshino M: Involvement of a Rac activator, P-Rex1, in neurotrophin-derived signaling and neuronal migration. J Neuros $\mathrm{Ci}$ 2005, 25(17):4406-4419.

99. Buffo A, Vosko MR, Erturk D, Hamann GF, Jucker M, Rowitch D, Gotz M: Expression pattern of the transcription factor Olig2 in response to brain injuries: implications for neuronal repair. Proc Natl Acad Sci USA 2005, 102(50):18183-18188.

100. Piper MDA, Lindwall C, Barry G, Plachez C, Richards LJ: Emx and Nfi genes regulate cortical development and axon guidance in the telencephalon. Novartis Found Symp 2007, 288:230-242.

101. Nakase T, Fushiki S, Naus CC: Astrocytic gap junctions composed of connexin 43 reduce apoptotic neuronal damage in cerebral ischemia. Stroke 2003, 34(8):1987-1993.

102. Lin JH, Lou N, Kang N, Takano T, Hu F, Han X, Xu Q, Lovatt D, Torres A, Willecke $K$, et al: A central role of connexin 43 in hypoxic preconditioning. J Neurosci 2008, 28(3):681-695.

103. Thiyagarajan M, Fernandez JA, Lane SM, Griffin JH, Zlokovic BV: Activated protein $\mathrm{C}$ promotes neovascularization and neurogenesis in postischemic brain via protease-activated receptor 1. J Neurosci 2008 , 28(48):12788-12797.

104. Taniguchi M, Yamashita T, Kumura E, Tamatani M, Kobayashi A, Yokawa T, Maruno M, Kato A, Ohnishi T, Kohmura E, et al.: Induction of aquaporin-4 water channel mRNA after focal cerebral ischemia in rat. Brain Res Mol Brain Res 2000, 78(1-2):131-137.

105. Li Q, Li Z, Mei Y, Guo Y: Neuregulin attenuated cerebral ischemiaCreperfusion injury via inhibiting apoptosis and upregulating aquaporin-4. Neurosci Lett 2008, 443(3):155-159.

106. Jia J, Chen X, Zhu W, Luo Y, Hua Z, Xu Y: CART protects brain from damage through ERK activation in ischemic stroke. Neuropeptides 2008, 42(5-6):653-661.

107. Mao P, Ardeshiri A, Jacks R, Yang S, Hurn PD, Alkayed NJ: Mitochondrial mechanism of neuroprotection by CART. Eur J Neurosci 2007, 26(3):624-632.

Pre-publication history

The pre-publication history for this paper can be accessed here: http://www.biomedcentral.com/1755-8794/3/27/prepub

doi: 10.1186/1755-8794-3-27

Cite this article as: Martijn and Wiklund, Effect of methylene blue on the genomic response to reperfusion injury induced by cardiac arrest and cardiopulmonary resuscitation in porcine brain BMC Medical Genomics 2010, 3:27

\section{Submit your next manuscript to BioMed Centra and take full advantage of:}

- Convenient online submission

- Thorough peer review

- No space constraints or color figure charges

- Immediate publication on acceptance

- Inclusion in PubMed, CAS, Scopus and Google Scholar

- Research which is freely available for redistribution 